\title{
Petrological and geochemical compositions of beach sands of the Barton and Weaver peninsulas of King George Island, West Antarctica: implications for provenance and depositional history
}

\author{
${ }^{1}$ School of Earth and Environmental Sciences, Seoul National University, Seoul 08826, Korea \\ ${ }^{2}$ Korea Polar Research Institute, Incheon 21990, Korea \\ ${ }^{3}$ Department of Energy Resources Engineering, Chosun University, Gwangju 61452, Korea \\ ${ }^{4}$ Department of Geological Sciences, Pusan National University, Busan 46241, Korea; *Corresponding author, E-mail: tracker@pusan.ac.kr
}

(Received: May 4, 2019; Revised accepted: May 20, 2019)

https://doi.org/10.18814/epiiugs/2019/019012

The provenance of modern beach sands from the Barton and Weaver peninsulas of King George Island, South Shetland Islands, West Antarctica was investigated based on their modal composition and geochemical data. The source rocks and provenance tectonic setting are interpreted as volcanic and plutonic rocks formed in the magmatic arc setting. This interpretation is generally consistent with the currently distributed bedrocks in the ice-free areas and tectonic setting of King George Island. However, the composition of beach sands of the Barton and Weaver peninsulas is different from distribution of bedrocks exposed in the ice-free areas of both peninsulas. The present beach sands are interpreted as previous subaqueous moraines that were eroded and transported by advancing glaciers across the both peninsulas and deposited in front of the glacier grounding line. In other words, sand sediments in the beaches of the two peninsulas were not derived from bedrocks currently exposed in ice-free areas, but it is interpreted that they were subaqueous moraines before deglaciation and were mixed with sediment derived from wave erosion of bedrocks and sediments of the paleoshoreline during the isostatic uplift of King George Island. Finally, they were reworked under the current beach environments.

\section{Introduction}

The petrological characteristics of the clastic sediments are influenced by factors such as the tectonic setting, lithology of source rocks, intensity of weathering, sediment transport process, depositional environment, and diagenesis (see Johnsson and Basu, 1993). The first two of these factors are related to each other, and may be the most important and dominating controls that affect the composition of sand sediments (sandstones). Geochemical composition of clastic sediments has been widely used to interpret the source rock characteristics (Loring and Asmund, 1996; Madhavaraju and Ramasamy, 2001; Lee et al.,
2005; Etemad-Saeed et al., 2015), weathering conditions in the source areas (Nesbitt and Young, 1982; Qiu et al. Al., 2014), and reconstruction of tectonic setting of sedimentary basins (Bhatia, 1983; Roser and Korsch, 1988; Verma and Armstrong-Altrin, 2013; Armstrong-Altrin, 2015). A combination of petrography and geochemical data is considered as a suitable approach for interpretation of the provenance of clastic sediments (Madhavaraju et al., 2010; El-Anwar and El-Wekeil, 2013; Armstrong-Altrin et al., 2015).

Many studies have been done on the texture and composition of beach sand sediments (e.g., Clemens and Komar, 1988; Carranza-Edwards and Rosales-Hoz, 1995; Morrone et al., 2017 amongst others). These studies provided information on the weathering conditions in the source regions, the slope of the coastal terrain, the relationship between sediment transport and energy related to waves and currents, and provenance of heavy minerals. In recent years, studies on the weathering in the source and the tectonic setting have been conducted actively using the geochemical composition of the beach sediments (Hegde et al., 2006; Carranza-Edwards et al., 2009; Armstrong-Altrin et al., 2012, 2014, 2015a, b; Barnard et al., 2013). The sediment production and depositional process acting on beach sediments in polar regions are different from those of tropical and temperate regions. In glacial settings, the effects of physical processes are the main factors involved in the formation and composition of sediments, while chemical processes are thought to be negligible (Nesbitt and Young, 1996). Loring and Asmund (1996) also reported that glaciomarine sediments in high latitude coastal and offshore regions are composed of physically comminuted but chemically undecomposed debris that have been derived from adjacent coastal rocks by glacial erosion and deposition. Accordingly, the chemistry of beach sediments would faithfully reflect the sediment mineralogy, which in turn is governed by the geology of the glacial terrain and adjacent coastline. However, there are no studies on beach sediments in polar regions we know of.

King George Island located in the South Shetland Islands (Fig. 1) is one of the volcanic islands that were formed by the subduction of the oceanic plate beneath the Antarctic Peninsula during the late Mesozoic to early Cenozoic era (Smellie et al., 1984). The Barton and Weaver peninsulas are located southwest of King George Island. Geological 
studies on these peninsulas have reported a geologic map (Lee et al., 2001), age of rocks (Park, 1989; Jin et al., 1991), and hydrothermal alteration (Park, 1991, So et al., 1995). However, there exists little study on modern beach sands of the two peninsulas. On both peninsulas, modern and raised beaches are distributed along the coastline. In many cases, the late Holocene beach sediments were uplifted and are composed mostly of rounded gravels (Lee, 1992; Koh et al., 1993). On modern beaches, sand-sized particles are distributed in a restricted area such as small pocket beaches and as matrix of gravel deposits. By studying texture, mineralogy, and geochemistry of modern beach sand samples collected from part of the Barton Peninsula, Choi et al. (2003) reported the sediment composition and speculated their depositional processes including iceberg rafting. In this study, we collected more beach sand samples distributed along all coastlines of the Barton and Weaver peninsulas. The purpose of this study is to reconstruct the provenance and tectonic setting of the Barton and Weaver peninsulas by using the modal and geochemical compositions of modern beach sandy sediments from both peninsulas. The results of this study are then compared with the geology of ice-free areas and a known tectonic setting of both peninsulas to propose the depositional process of modern beach sands.

\section{Geological Setting}

The Barton and Weaver peninsulas are located on King George Island in the South Shetland Islands off the northernmost tip of the Antarctic Peninsula (Fig. 1). The South Shetland Islands belong to part of magmatic arcs (Scotia Arc), which is closely linked to the formation of the Antarctic Peninsula (Smellie et al., 1984). King George Island is the largest island of the South Shetland Islands and is located in the center of the archipelago. The Barton and Weaver peninsulas are located at the southwestern end of the island, which is mostly covered by Sejong Ice Cap (Yoon et al., 2010). The ice-free area of the Barton Peninsula has a gentle topography with a wide central plain lying at 90-180 m above sea level. The ice-free area of the Weaver Peninsula is smaller in size and lower in altitude than the Barton Peninsula, and consists of a central plain. King George Island is undergoing an isostatic uplift after the removal of the ice sheet (Barsch and Mäusbacher, 1986). The morphology of both peninsulas is predominantly characterized by a glacial landscape, in parts steep cliffs along the coast, and a rather smooth, hilly interior. Both peninsulas are separated by a small tributary fjord, Marian Cove, which has a length of ca. $4.5 \mathrm{~km}$, a width of ca. $1.5 \mathrm{~km}$, and a maximum depth of $120 \mathrm{~m}$. The outlet of the cove is Maxwell Bay, the main fjord formed during the Last Glacial Maximum (LGM), and the cove is bounded by the Weaver Peninsula to the northwest and the Barton Peninsula to the southeast (Simms et al., 2011). Marian Cove has been enlarging towards northeast since $1.7 \mathrm{ka}$ by ice cliff retreating (Simms et al., 2011). Retreat of $1,050 \mathrm{~m}$ in length of the ice cliff in Marian Cove has occurred between 1956 and 2001 (Chung et al., 2004). The retreat rates have since increased from $6 \mathrm{~m} / \mathrm{yr}$ of the first investigated period to 54 and $81 \mathrm{~m} / \mathrm{yr}$ in recent years.

During the LGM, King George Island was covered by a large ice cap and the Barton and Weaver peninsulas became progressively ice free since the LGM (Chang et al., 2003). Based on cosmogenic ${ }^{36} \mathrm{Cl}$ age-dating, Seong et al. (2009) reported that the exposure age of the highest areas on the Barton Peninsula was $15.5 \pm 2.5 \mathrm{ka}$, which represents the timing of the beginning of deglaciation. They further suggested that the Marian Cove Glacier has been progressively downwasted since the LGM up to the present at a long-term rate of $\sim 12 \mathrm{~mm} / \mathrm{yr}$ on the Barton and Weaver peninsulas. The deglaciation from Maxwell Bay occurred around 14.1-14.8 ka and Maxwell Bay gradually became open ocean conditions since $9.1 \mathrm{ka}$ by retreat of persistent ice cover, possibly an ice shelf (Simms et al., 2011).

Much of the bedrock in ice-free areas of both peninsulas is covered by glacial till. Landscapes modified by periglaciation are widespread. The ice-free areas comprises five geomorphic elements, bedrock, glacial till, mechanical weathering products, patterned ground, and raised beach (Araya and Hervé, 1972). Bedrock is exposed in places where debris is difficult to accumulate, such as high peaks and cliffs. The glacial till remains at the end of ice where it flowed down or where ice had been pushed past, and is most widely distributed. Mechanical weathering products are distributed at the foot of steep slopes. Patterned ground is distributed in the central parts of both peninsulas and there are two types of patterned ground according to the slope of the ground: polygons and sorted stripes. Raised beaches are distributed in geographically low areas along the coast (Chang et al., 2003). The Barton and Weaver peninsulas are drained by small seasonal streams (López-Martínez et al., 2012).

The Barton Peninsula has the ice-free area 5 times larger than the Weaver Peninsula. The geology of the ice-free areas in the Weaver and Barton peninsulas is somewhat different (Fig. 1). The Barton and Weaver peninsulas are composed of three lithologies: volcaniclastics (the Sejong Formation), calc-alkaline volcanic rocks, and the intrusive rocks (Lee et al., 2001). The Sejong Formation forms the lowest stratigraphic unit in both the Barton and Weaver peninsulas and is of Eocene in age (Yoo et al., 2001). The maximum thickness is about $200 \mathrm{~m}$. In the Barton Peninsula it is distributed in the southwestern and southern parts forming cliffs close to the coastline, whereas in the Weaver Peninsula the Sejong Formation is distributed in most of the ice-free area. It is composed of subaerial volcaniclastic sediments such as agglomerate, tuff breccia, and lapilli tuff(Yoo et al., 2001; Kim et al., 2005).

Mafic to intermediate volcanic rocks overlie the Sejong Formation and are most widely distributed in the Barton Peninsula, but in the Weaver Peninsula they are narrowly present only in the southwestern and northern parts. Although the eruption timing is not precisely specified, most of the lava is believed to have erupted in the Eocene (Jwa et al., 1992; Willan and Armstrong, 2002). Most of these lava flows are basaltic andesite containing plagioclase or pyroxene phenocrysts and are associated with some massive andesites. Two fairly thick lapilli tuffs are intercalated in the lava flows in the eastern part of the Barton Peninsula. In the central northwestern part of the Barton Peninsula, there are very small mass of fine-crystalline diorite and relatively large stock of medium-crystalline granodiorite. The whole-rock ${ }^{40} \mathrm{Ar}{ }^{\beta 9} \mathrm{Ar}$ age of the diorite is $48.4 \pm 0.5 \mathrm{Ma}$ (Early Eocene; Kim et al., 2000 ) and the $\mathrm{K}-\mathrm{Ar}$ ages of two biotite crystals isolated from the granodiorite are $41.9 \pm 0.9 \mathrm{Ma}$ and $41.2 \pm 0.9 \mathrm{Ma}$ (Lee et al., 1996).

The volcanic rocks surrounding the granodiorite in the Barton Peninsula were mostly altered extensively by hydrothermal fluids and in some parts they were altered multiple times. This hydrothermal alteration is interpreted as a consequence of shallow hydrothermal pro- 


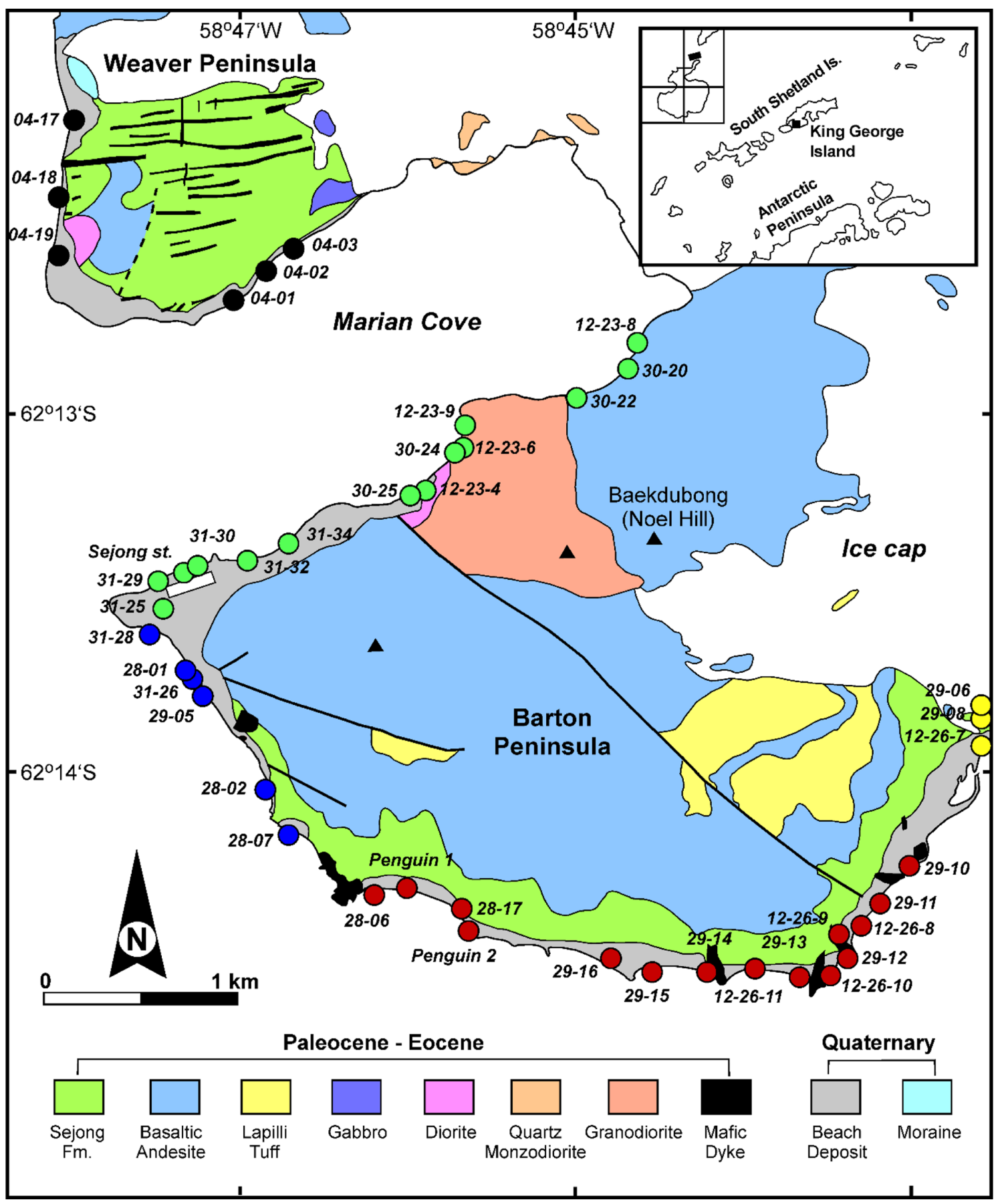

Fig. 1. Geological map of the Barton and Weaver peninsulas, King George Island, West Antarctica. The inset shows the location of King George Island (simplified from Lee et al., 2001). Solid circles are the sampling locations (black: Weaver, green: NW Barton, blue: SW Barton, red: S Barton, yellow: SE Barton).

cesses associated with the intrusion of granodiorite (Hwang and Lee, 1998). The hydrothermal alteration zone in direct contact with the granodiorite is dominated by chloritization of amphiboles and albitization, but sericitization of feldspars occurs as distance increases, and kaolinitization of sericite becomes more dominant at a further distance (Hur et al., 2001). In the Barton Peninsula, three nearly parallel strike-slip faults develop in the northwest-southeast direction.

Most of the sediments that make up the beach of the Barton and Weaver peninsulas consist of particles over gravel size, and the sand beach is present in places between gravel beaches and in places protected by beach gravels. The fact that the beach sediments of the both Barton and Weaver peninsulas are composed of gravels indicates that the studied beaches are under strong wave energy influenced by strong winds (Choi et al., 2003). The wind field in Maxwell Bay is distinctly bidirectional (Klöser et al., 1994) with predominant wind direction of $\mathrm{E}$ or NW throughout the year. Both Marian Cove and Maxwell Bay are covered by sea ice from June to October and are usually open ocean frequently covered with drift ice along the shore 
from November to May.

In Marian Cove, eastern winds will inhibit the inflow from and enhance outflow to Maxwell Bay, whereas northwesterly to westerly winds generates a cyclonic circulation with an enhanced inflow to the cove and a retarded outflow (Yoo et al., 2015). There is no well-developed longshore currents along the coastlines of both peninsulas. The tidal range of Marian Cove is less than $2 \mathrm{~m}$ (Yoo et al., 2015), and it is considered less likely that sediment is transported from other coastal zones of Maxwell Bay and accumulated on the beaches of the two peninsulas. However, in coastal areas along Marian Cove, it is believed that some sediments would be transported by meltwater from the Marian Cove head.

\section{Methods}

A total of 32 sand samples (26 samples from the Barton Peninsula and 6 samples from the Weaver Peninsula) were collected at the present-day coastlines of the Barton and Weaver peninsulas and were observed using a polarizing microscope after making thin sections. Each sample was examined for modal composition using quartz, feldspar, rock fragment, and accessory grains by counting 500 points.

Chemical compositions of sand samples were analyzed at the Korea Basic Science Institute. Each sample was powdered in an agate motar. Major elements of sand samples were analyzed using X-ray fluorescence spectroscopy (XRF: Philips PW244 model) and the analyzed elements are $\mathrm{Si}, \mathrm{Al}, \mathrm{Fe}, \mathrm{Ca}, \mathrm{Na}, \mathrm{Mg}, \mathrm{K}, \mathrm{P}, \mathrm{Ti}$, and $\mathrm{Mn}$. The analytical error of the major elements is $\pm 5 \%$. Each sample was analyzed three times, and the results were then averaged. Total Fe content is reported as $\mathrm{Fe}_{2} \mathrm{O}_{3}$. Loss on ignition (LOI) was measured by weighing before and after $1 \mathrm{~h}$ of calcination at $1000^{\circ} \mathrm{C}$. Rare earth elements (REE) were analyzed using an inductively coupled plasma mass spectrometer (ICP-MS: VG Elemental PQII Plus model). The accuracy of the REE analysis is better than $5 \%$. In this paper, the median is used as the summary statistic because it provides a robust estimate of central tendency for datasets drawn from a population whose distribution pattern is unknown (Lister, 1982; Rock et al., 1987).

\section{Results}

\section{Sand Composition}

Particle size of beach sand samples from the Barton and Weaver peninsulas belongs mostly to coarse-sand grade as reported in Choi et al. (2003), and the sorting is good to moderately good. The modal compositions of the studied beach sand samples are combined with the results of Choi et al. (2003) and are shown in Table 1. The components of sand grains were categorized into nine types: volcanic rock fragment, plutonic rock fragment, sedimentary rock fragment, monocrystalline quartz, polycrystalline quartz, plagioclase, heavy mineral, altered grain, and other unidentified grain. K-feldspar does not occur as a single sand grain except for its occurrence in igneous rock fragment. Most of the sand grains are volcanic rock fragment, altered grain, and plutonic rock fragment (Fig. 2). Volcanic rock fragment has microlitic and lathwork textures, with the latter being slightly higher content (Choi et al., 2003; this study). Particles other than volcanic rock fragment, altered grain, and plutonic rock fragment have low contents less than

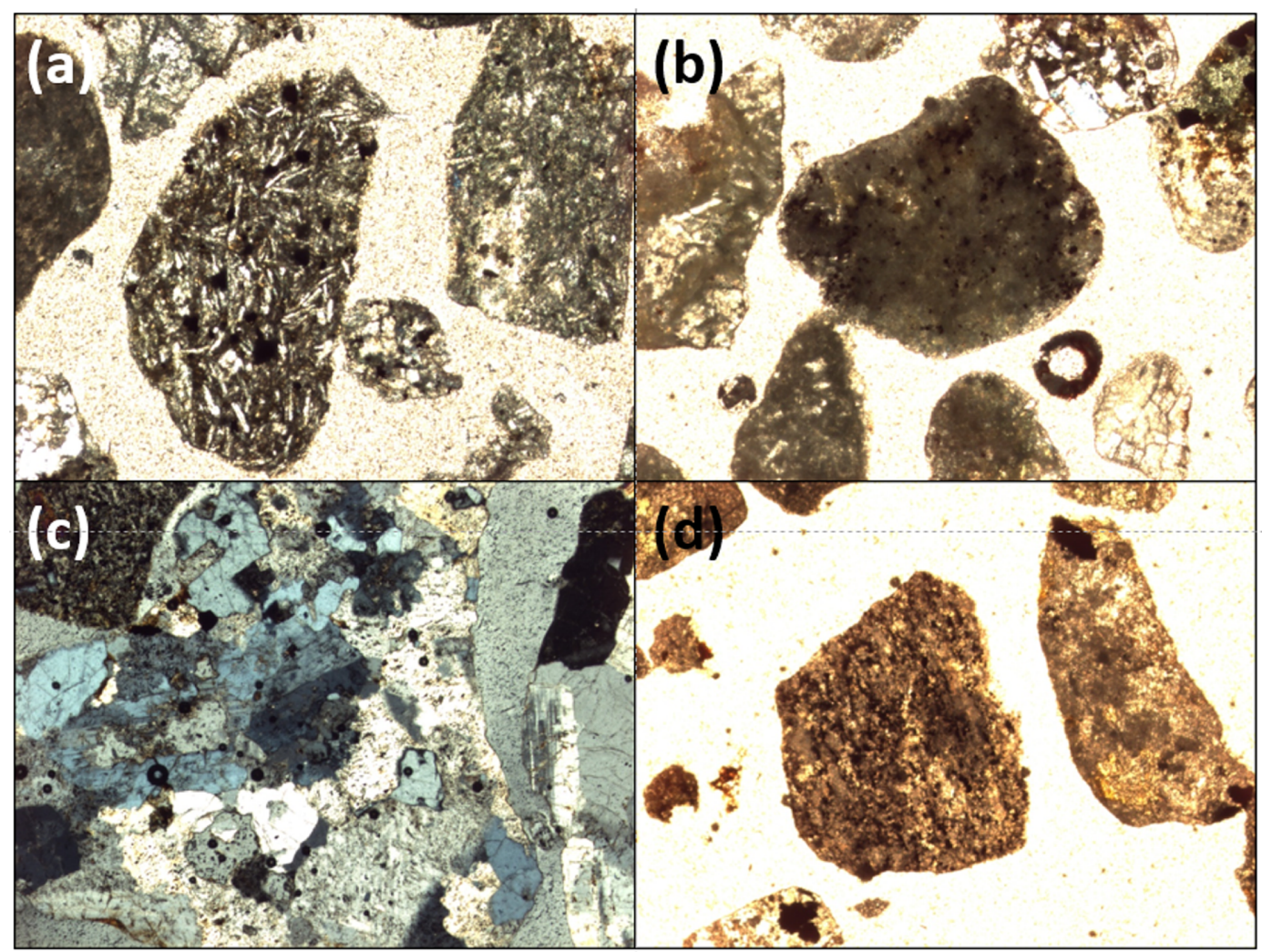

Fig. 2. Representative of (a) volcanic rock fragment, (b) altered grains, (c) igneous rock fragment, and (d) possible altered ignimbrite fragment. 

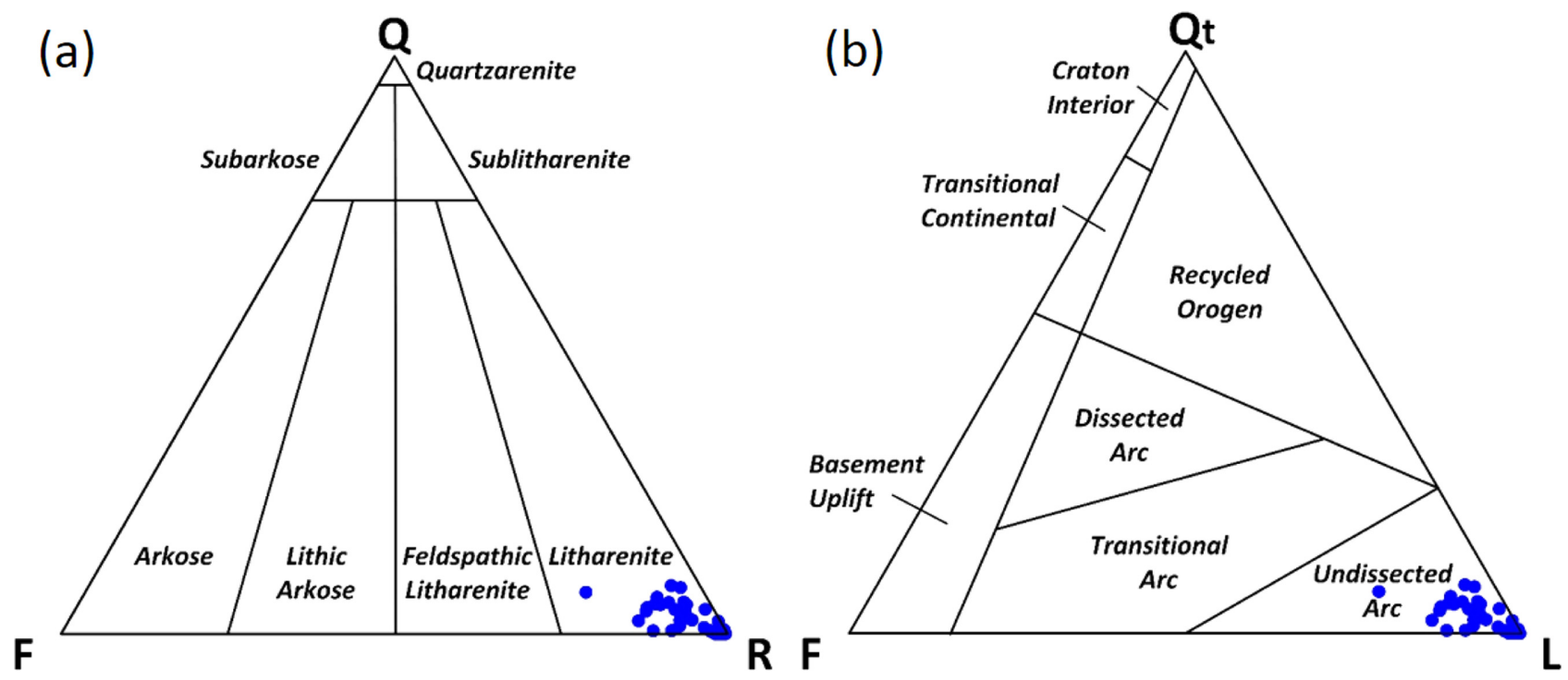

Fig. 3. (a) Sandstone classification (after Folk, 1974) and (b) clast source terrane (after Dickinson, 1985) of the Barton and Weaver peninsulas' beaches. Beach sands of both peninsulas are classified as lithic arenite and plot in the undissected arc field. Q: total quartz; F: total feldspar [K(potash feldspar) + P(plagioclase)]; $R$ and L: total lithic fragments.

$10 \%$ of the framework grains. The altered grains are severely altered, making it difficult to distinguish the original rock component. However, considering very little chemical weathering of soil (Lee et al., 2004), most of the altered grains are regarded as a rock fragment derived from hydrothermally altered volcanic rocks. Altered pyroclastic rock fragments are rarely visible (Fig. 2d).

The average quartz-feldspar-rock fragment $(\mathrm{Q}-\mathrm{F}-\mathrm{R})$ ratio of the beach sands of the Weaver Peninsula is $\mathrm{Q}_{3.4}-\mathrm{F}_{5.5}-\mathrm{R}_{91.1}$. In the Barton Peninsula the average $\mathrm{Q}-\mathrm{F}-\mathrm{R}$ ratio of the beach sands of the northwestern beach is $\mathrm{Q}_{2.9}-\mathrm{F}_{8.3}-\mathrm{R}_{88.8}$, of the southwestern beach is $\mathrm{Q}_{1.7}-\mathrm{F}_{3.8}-\mathrm{R}_{94.5}$, and of the southern beach is $Q_{0.2}-F_{1.2}-R_{98.6}$, and of the southeastern beach is $\mathrm{Q}_{0.0}-\mathrm{F}_{1.7}-\mathrm{R}_{98.3}$. Beach sediments of both peninsulas all plot in the litharenite clan with tight clustering (Fig. 3a). In addition, the studied beach sand samples plot in undissected-arc setting field in a tectonic environment-discriminating QFL diagram of Dickinson (1985) (Fig. 3b).

The modal composition of beach sand samples is divided into two groups. One group consists of sand samples of the Weaver Peninsula and the northwestern beach of the Barton Peninsula, and the other group consists of sand samples from the southwestern, southern, and southeastern beaches of the Barton Peninsula. The modal composition of the first group samples is almost identical. The median values of volcanic rock fragment content in sand samples from the Weaver Peninsula beach and the northwestern beach of the Barton Peninsula were $31.9 \%$ and $30.9 \%$ of the framework grains, respectively. The median values of igneous rock fragment content were $17.4 \%$ and $17.6 \%$, respectively, and median plagioclase contents were $5.3 \%$ and $7.4 \%$, respectively. The median quartz content is low, accounting for $3.0 \%$, and $2.7 \%$, respectively. In the second group, the median values of volcanic rock fragment in sand samples of the southwestern, southern, and southeastern beaches of the Barton Peninsula were $40.8 \%, 48.3 \%$, and $51.7 \%$, respectively, while the median values of igneous rock fragment were $7.4 \%, 3.2 \%$, and $1.7 \%$ and the median values of plagioclase content are $4.0 \%, 1.0 \%$, and $1.6 \%$, respectively. Quartz grain occurs only in the southwestern beach sands (mean $2.1 \%$ ). The median value of the altered grain is
$28.7 \%$ in the first group and $33.6-38.8 \%$ in the second group. In summary, the samples of the first group have lower contents of volcanic rock fragment and altered grain, while the contents of igneous rock fragment and plagioclase are higher than those of the second group in the Barton Peninsula.

\section{Chemical Composition}

The major element data of Barton and Weaver peninsulas beach sands are listed in Table 2, in which the major element data of this study are combined with data of Choi et al. (2003). Unlike the modal compositions (Table 1), there is no significant difference in the composition of the major elements of beach sand samples between the Weber Peninsula and the Barton Peninsula, but there is a slight difference in the contents of $\mathrm{SiO}_{2}, \mathrm{Al}_{2} \mathrm{O}_{3}$, and $\mathrm{MgO}$. The median values of $\mathrm{SiO}_{2}, \mathrm{Al}_{2} \mathrm{O}_{3}$, and $\mathrm{MgO}$ contents of the Weaver Peninsula beach sands are $56.5 \%, 18.1 \%$, and $3.3 \%$, respectively, while the median values of $\mathrm{SiO}_{2}, \mathrm{Al}_{2} \mathrm{O}_{3}$, and $\mathrm{MgO}$ contents of sand samples in different beaches of the Barton Peninsula range 58.4-62.7\%, 15.2-16.7\%, and 2.3-2.8\%, respectively. Thus, the $\mathrm{SiO}_{2}$ content is higher in the Barton Peninsula beach sands, whereas the $\mathrm{Al}_{2} \mathrm{O}_{3}$ and $\mathrm{MgO}$ contents are higher in the Weber Peninsula beach sands.

In all sand samples the contents of $\mathrm{CaO}$ and $\mathrm{Na}_{2} \mathrm{O}$ are much higher than that of $\mathrm{K}_{2} \mathrm{O}$. In particular, the ratio of $\mathrm{Na}_{2} \mathrm{O} / \mathrm{K}_{2} \mathrm{O}$ is $1.4-6.3$ with an average of 3.3, which is consistent with the results of microscopic observation of plagioclase grain but no observed K-feldspar grain. Based on the chemical classification diagram of Pettijohn et al. (1972), all the beach sand samples of the Weaver and Barton peninsulas are classified as graywacke type (Fig. 4). The correlation between the contents of $\mathrm{Fe}_{2} \mathrm{O}_{3}$ and $\mathrm{TiO}_{2}$ is statistically significant (Pearson product moment correlation coefficient $=0.696, p=<0.001$ ). Therefore, it is interpreted that the studied beach sands contain minerals rich in Fe and Ti. According to the microscopic observation, the corresponding mineral is presumed to be magnetite contained in volcanic rock fragments. 
Table 1. Modal compositions of beach sands from the Barton and Weaver peninsulas, King George Island, West Antarcica

\begin{tabular}{|c|c|c|c|c|c|c|c|c|c|}
\hline Sample & VRF (\%) & PRF (\%) & SRF (\%) & Qm (\%) & Qp (\%) & $\mathrm{Pl}(\%)$ & HM (\%) & Alt (\%) & Etc $(\%)$ \\
\hline \multicolumn{10}{|c|}{ Weaver Peninsula } \\
\hline 04-01 & 28.2 & 24.0 & 7.2 & 3.8 & 0.0 & 5.8 & 3.2 & 24.4 & 3.4 \\
\hline $04-02$ & 28.8 & 19.6 & 9.2 & 2.6 & 0.2 & 5.6 & 2.8 & 28.6 & 2.6 \\
\hline $04-03$ & 25.2 & 23.8 & 7.8 & 3.8 & 0.6 & 7.2 & 2.0 & 26.6 & 3.0 \\
\hline $04-17$ & 37.6 & 11.4 & 3.2 & 2.2 & 0.6 & 3.8 & 3.4 & 34.4 & 3.4 \\
\hline 04-18 & 38.2 & 15.2 & 1.8 & 2.0 & 0.2 & 5.0 & 2.2 & 28.8 & 6.6 \\
\hline 04-19 & 35.0 & 12.2 & 4.6 & 3.0 & 0.0 & 3.4 & 4.0 & 33.2 & 4.6 \\
\hline median & 31.9 & 17.4 & 5.9 & 2.8 & 0.2 & 5.3 & 3.0 & 28.7 & 3.4 \\
\hline \multicolumn{10}{|c|}{ Barton Peninsula } \\
\hline \multicolumn{10}{|c|}{ Northwestern beach } \\
\hline $30-20$ & 24.6 & 14.4 & 12.2 & 4.6 & 0.6 & 4.2 & 3.2 & 33.6 & 2.6 \\
\hline $30-22$ & 23.6 & 21.8 & 7.6 & 1.4 & 0.0 & 4.0 & 2.0 & 36.6 & 3.0 \\
\hline $30-24$ & 36.2 & 17.6 & 0.2 & 2.2 & 0.4 & 9.4 & 6.4 & 24.4 & 3.2 \\
\hline $30-25$ & 53.0 & 14.6 & 1.8 & 1.8 & 0.2 & 4.4 & 1.6 & 21.4 & 1.2 \\
\hline $31-25$ & 34.6 & 15.2 & 5.6 & 3.6 & 0.0 & 7.2 & 2.0 & 27.4 & 4.4 \\
\hline $31-29$ & 33.0 & 17.6 & 7.0 & 3.6 & 0.0 & 7.8 & 2.6 & 23.8 & 4.6 \\
\hline $31-30$ & 27.4 & 20.6 & 5.0 & 3.0 & 0.0 & 9.4 & 3.2 & 28.8 & 2.6 \\
\hline $31-32$ & 24.6 & 19.8 & 4.4 & 1.2 & 0.2 & 11.6 & 4.2 & 32.2 & 1.8 \\
\hline $31-34$ & 29.8 & 19.0 & 3.4 & 3.2 & 0.0 & 7.2 & 3.4 & 30.8 & 3.2 \\
\hline $12-23-4^{*}$ & 52.0 & 11.0 & 3.3 & 1.0 & 0.0 & 6.3 & 3.0 & 23.0 & 0.3 \\
\hline $12-23-6^{*}$ & 37.0 & 14.0 & 3.3 & 0.0 & 0.3 & 7.7 & 6.0 & 31.7 & 0.0 \\
\hline $12-23-8^{*}$ & 16.7 & 29.7 & 1.0 & 4.3 & 0.7 & 16.0 & 9.3 & 20.7 & 1.7 \\
\hline $12-23-9 *$ & 21.7 & 18.0 & 9.3 & 3.3 & 1.3 & 3.0 & 4.7 & 37.7 & 1.0 \\
\hline Sejong st.* & 32.0 & 17.0 & 6.0 & 0.3 & 0.0 & 10.3 & 5.7 & 28.7 & 0.0 \\
\hline median & 30.9 & 17.6 & 4.7 & 2.6 & 0.1 & 7.4 & 3.3 & 28.7 & 2.2 \\
\hline \multicolumn{10}{|c|}{ Southwestern beach } \\
\hline $28-01$ & 38.6 & 11.6 & 3.8 & 3.2 & 0.2 & 3.6 & 4.0 & 30.2 & 4.8 \\
\hline $28-02$ & 40.6 & 7.2 & 4.6 & 2.4 & 0.0 & 1.2 & 3.2 & 37.2 & 3.6 \\
\hline $28-07$ & 45.4 & 5.0 & 3.4 & 0.0 & 0.0 & 1.8 & 0.2 & 40.6 & 3.6 \\
\hline $29-05$ & 41.6 & 5.2 & 2.6 & 1.8 & 0.2 & 4.4 & 3.0 & 38.6 & 2.6 \\
\hline $31-26$ & 39.8 & 12.6 & 3.2 & 2.2 & 0.0 & 5.0 & 2.2 & 31.4 & 3.6 \\
\hline $31-28$ & 41.0 & 7.6 & 3.8 & 1.2 & 0.2 & 5.6 & 3.8 & 33.2 & 3.6 \\
\hline median & 40.8 & 7.4 & 3.6 & 2.0 & 0.1 & 4.0 & 3.1 & 35.2 & 3.6 \\
\hline \multicolumn{10}{|l|}{ Southern beach } \\
\hline $28-06$ & 42.2 & 6.8 & 2.0 & 0.4 & 0.2 & 2.8 & 4.8 & 38.8 & 2.0 \\
\hline $29-10$ & 46.2 & 4.2 & 3.6 & 0.0 & 0.0 & 0.8 & 1.2 & 42.6 & 1.4 \\
\hline $29-11$ & 48.8 & 3.2 & 4.6 & 0.2 & 0.0 & 1.4 & 2.4 & 34.8 & 4.6 \\
\hline $29-12$ & 45.2 & 4.4 & 1.6 & 0.0 & 0.2 & 2.2 & 1.8 & 41.4 & 3.2 \\
\hline $29-13$ & 49.8 & 0.8 & 1.2 & 0.0 & 0.0 & 0.4 & 6.6 & 38.8 & 2.4 \\
\hline $29-14$ & 44.2 & 5.2 & 3.4 & 0.0 & 0.0 & 1.8 & 2.2 & 39.6 & 3.6 \\
\hline $29-15$ & 49.2 & 3.0 & 1.6 & 0.0 & 0.0 & 1.0 & 3.6 & 39.0 & 2.6 \\
\hline $29-16$ & 47.6 & 2.4 & 2.6 & 0.2 & 0.0 & 1.2 & 3.8 & 40.8 & 1.4 \\
\hline $29-17$ & 44.8 & 6.2 & 4.6 & 0.4 & 0.0 & 0.2 & 5.8 & 35.2 & 2.8 \\
\hline $12-26-8^{*}$ & 48.3 & 2.0 & 4.7 & 0.0 & 0.0 & 1.3 & 0.7 & 43.0 & 0.0 \\
\hline $12-26-9 *$ & 45.7 & 1.0 & 0.7 & 0.0 & 0.0 & 1.3 & 1.7 & 49.7 & 0.0 \\
\hline $12-26-10^{*}$ & 51.3 & 3.3 & 3.3 & 0.3 & 0.0 & 0.7 & 4.7 & 36.3 & 0.0 \\
\hline $12-26-11^{*}$ & 54.0 & 1.7 & 0.7 & 0.0 & 0.0 & 1.0 & 5.7 & 36.7 & 0.3 \\
\hline Penguin $1^{*}$ & 57.0 & 2.3 & 1.7 & 0.0 & 0.0 & 0.3 & 1.0 & 37.7 & 0.0 \\
\hline Penguin 2* & 50.3 & 5.7 & 3.0 & 1.3 & 0.0 & 0.3 & 4.7 & 33.7 & 1.0 \\
\hline median & 48.3 & 3.2 & 2.6 & 0.0 & 0.0 & 1.0 & 3.6 & 38.8 & 1.4 \\
\hline
\end{tabular}


Table 1. Continued

\begin{tabular}{|c|c|c|c|c|c|c|c|c|c|}
\hline \multicolumn{10}{|l|}{ Southeasten beach } \\
\hline $29-06$ & 54.2 & 0.8 & 5.6 & 0.0 & 0.0 & 1.6 & 3.4 & 32.6 & 1.8 \\
\hline $29-08$ & 51.4 & 1.8 & 5.2 & 0.0 & 0.0 & 1.4 & 3.0 & 33.6 & 3.6 \\
\hline $12-26-7^{*}$ & 51.7 & 1.7 & 4.7 & 0.3 & 0.0 & 2.3 & 4.0 & 35.0 & 0.3 \\
\hline median & 51.7 & 1.7 & 5.2 & 0.0 & 0.0 & 1.6 & 3.4 & 33.6 & 1.8 \\
\hline
\end{tabular}

VRF: volcanic rock fragment; PRF: plutonic rock fragment; SRF: sedimentary rock fragment; Qm: monocrystalline quartz; Qp: polycrystalline quartz; Pl: plagioclase; HM: heavy mineral; Alt: altered grain; Etc: other component

*Choi et al. (2003) based on 300 pointing counts.

Table 2. The major element compositions of beach sand samples from the Barton and Weaver peninsulas, King George Island, West Antarctica

\begin{tabular}{|c|c|c|c|c|c|c|c|c|c|c|c|c|c|}
\hline Sample & $\mathrm{SiO}_{2}$ & $\mathrm{Al}_{2} \mathrm{O}_{3}$ & $\mathrm{Fe}_{2} \mathrm{O}_{3}{ }^{*}$ & $\mathrm{CaO}$ & $\mathrm{Na}_{2} \mathrm{O}$ & $\mathrm{MgO}$ & $\mathrm{K}_{2} \mathrm{O}$ & $\mathrm{P}_{2} \mathrm{O}_{5}$ & $\mathrm{TiO}_{2}$ & $\mathrm{MnO}$ & L.O.I & Total & CIA \\
\hline \multicolumn{14}{|c|}{ Weaver Peninsula } \\
\hline 04-01 & 57.5 & 18.0 & 7.87 & 5.10 & 3.66 & 3.19 & 0.95 & 0.20 & 0.75 & 0.17 & 2.42 & 99.7 & 52.4 \\
\hline $04-02$ & 57.1 & 18.4 & 7.42 & 4.63 & 3.70 & 3.31 & 1.03 & 0.18 & 0.72 & 0.15 & 2.81 & 99.5 & 54.1 \\
\hline $04-03$ & 55.9 & 18.1 & 8.93 & 5.60 & 3.35 & 3.56 & 0.98 & 0.17 & 0.83 & 0.18 & 2.43 & 100.1 & 52.0 \\
\hline $04-17$ & 58.0 & 17.1 & 8.16 & 5.01 & 3.31 & 2.86 & 1.24 & 0.21 & 0.80 & 0.16 & 2.46 & 99.3 & 51.8 \\
\hline 04-18 & 55.9 & 18.0 & 8.62 & 5.84 & 3.48 & 3.15 & 0.91 & 0.20 & 0.81 & 0.17 & 2.38 & 99.4 & 50.9 \\
\hline $04-19$ & 55.6 & 18.2 & 8.53 & 5.69 & 3.47 & 3.33 & 0.93 & 0.20 & 0.78 & 0.17 & 2.39 & 99.3 & 51.6 \\
\hline median & 56.5 & 18.1 & 8.3 & 5.3 & 3.5 & 3.3 & 1.0 & 0.2 & 0.8 & 0.2 & 2.4 & 99.4 & 51.9 \\
\hline \multicolumn{14}{|c|}{ Barton Peninsula } \\
\hline \multicolumn{14}{|c|}{ Northwestern beach } \\
\hline $30-23$ & 64.9 & 15.8 & 5.49 & 3.49 & 3.23 & 1.94 & 2.22 & 0.12 & 0.62 & 0.13 & 2.36 & 100.3 & 52.9 \\
\hline $31-34$ & 61.3 & 16.7 & 6.67 & 4.29 & 3.68 & 2.59 & 1.25 & 0.19 & 0.78 & 0.15 & 2.66 & 100.2 & 52.3 \\
\hline $12-23-4 *$ & 62.0 & 16.8 & 5.53 & 4.76 & 3.88 & 2.41 & 1.35 & 0.10 & 0.69 & 0.12 & 2.26 & 99.9 & 50.4 \\
\hline $12-23-6^{*}$ & 63.4 & 17.7 & 5.02 & 4.09 & 3.92 & 2.35 & 1.42 & 0.09 & 0.65 & 0.11 & 2.17 & 99.9 & 53.4 \\
\hline $12-23-8^{*}$ & 60.7 & 17.7 & 7.13 & 2.31 & 2.51 & 2.29 & 1.84 & 0.11 & 0.71 & 0.09 & 4.48 & 99.8 & 63.2 \\
\hline $12-23-9^{*}$ & 63.3 & 16.4 & 5.68 & 4.70 & 3.66 & 1.97 & 1.72 & 0.12 & 0.70 & 0.11 & 1.75 & 100.2 & 50.0 \\
\hline Sejong st.* & 60.4 & 17.3 & 6.17 & 5.02 & 3.80 & 2.80 & 1.31 & 0.17 & 0.70 & 0.12 & 2.31 & 100.1 & 50.8 \\
\hline median & 62.7 & 16.7 & 5.6 & 4.2 & 3.7 & 2.3 & 1.6 & 0.1 & 0.7 & 0.1 & 2.3 & 100.0 & 53.7 \\
\hline \multicolumn{14}{|c|}{ Southwestern beach } \\
\hline $28-02$ & 58.9 & 16.3 & 8.18 & 4.60 & 3.62 & 2.78 & 1.12 & 0.28 & 0.90 & 0.17 & 2.60 & 99.5 & 51.2 \\
\hline $28-03$ & 57.9 & 16.1 & 9.65 & 5.01 & 3.50 & 2.89 & 1.14 & 0.30 & 1.06 & 0.19 & 2.72 & 100.5 & 50.0 \\
\hline $29-05$ & 57.3 & 17.3 & 8.25 & 4.67 & 3.45 & 3.18 & 1.17 & 0.25 & 0.84 & 0.17 & 3.04 & 99.7 & 52.8 \\
\hline $31-28$ & 60.3 & 16.6 & 6.54 & 4.00 & 3.90 & 2.79 & 1.16 & 0.20 & 0.75 & 0.15 & 2.80 & 99.2 & 52.6 \\
\hline median & 58.4 & 16.5 & 8.2 & 4.6 & 3.6 & 2.8 & 1.1 & 0.3 & 0.9 & 0.2 & 2.8 & 99.6 & 51.4 \\
\hline \multicolumn{14}{|c|}{ Southern beach } \\
\hline $29-15$ & 59.8 & 15.8 & 8.12 & 3.72 & 4.32 & 2.37 & 0.69 & 0.30 & 0.96 & 0.16 & 3.00 & 99.3 & 52.0 \\
\hline $12-26-8^{*}$ & 60.8 & 15.3 & 7.87 & 3.33 & 4.28 & 2.49 & 1.21 & 0.22 & 0.86 & 0.13 & 3.44 & 99.9 & 51.5 \\
\hline $12-26-9 *$ & 56.3 & 15.8 & 8.53 & 5.03 & 3.93 & 3.05 & 0.97 & 0.32 & 1.33 & 0.13 & 4.69 & 100.1 & 48.6 \\
\hline $12-26-10^{*}$ & 62.0 & 15.2 & 7.68 & 3.47 & 3.84 & 2.35 & 1.14 & 0.25 & 0.85 & 0.12 & 2.95 & 99.8 & 52.3 \\
\hline $12-26-11^{*}$ & 60.4 & 15.9 & 7.92 & 5.17 & 3.90 & 2.26 & 0.77 & 0.17 & 0.97 & 0.15 & 2.43 & 100.1 & 48.9 \\
\hline Penguin $1^{*}$ & 59.1 & 16.1 & 7.88 & 5.75 & 3.53 & 2.76 & 1.07 & 0.30 & 1.00 & 0.15 & 2.62 & 100.3 & 48.1 \\
\hline Penguin $2^{*}$ & 55.8 & 16.1 & 9.26 & 6.05 & 3.68 & 2.99 & 0.96 & 0.28 & 1.04 & 0.17 & 3.46 & 99.8 & 47.1 \\
\hline median & 59.8 & 15.8 & 7.9 & 5.0 & 3.9 & 2.5 & 1.0 & 0.3 & 1.0 & 0.2 & 3.0 & 99.9 & 48.8 \\
\hline \multicolumn{14}{|c|}{ Southeastern beach } \\
\hline $29-09$ & 61.9 & 15.3 & 8.01 & 3.20 & 3.89 & 2.29 & 1.24 & 0.30 & 0.84 & 0.14 & 2.98 & 100.1 & 53.0 \\
\hline $12-26-7^{*}$ & 63.2 & 15.1 & 6.86 & 3.11 & 4.09 & 2.23 & 1.22 & 0.20 & 0.81 & 0.11 & 2.91 & 99.8 & 52.3 \\
\hline median & 62.6 & 15.2 & 7.4 & 3.2 & 4.0 & 2.3 & 1.2 & 0.3 & 0.8 & 0.1 & 2.9 & 100.0 & 52.7 \\
\hline
\end{tabular}

*Choi et al. (2003). 


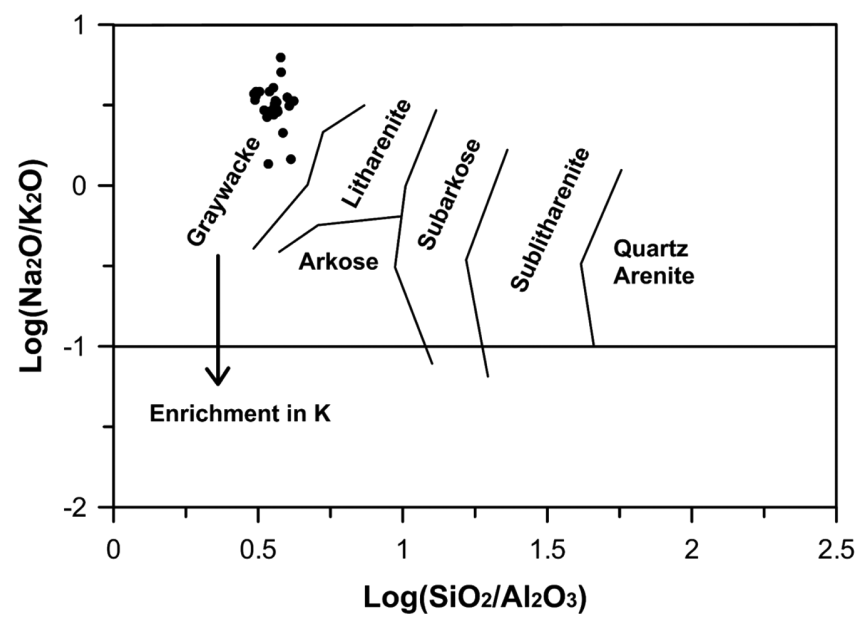

Fig. 4. Geochemical classification using $\log \left(\mathrm{Na}_{2} \mathrm{O} / \mathrm{K}_{2} \mathrm{O}\right)$ versus log $\left(\mathrm{SiO}_{2} / \mathrm{Al}_{2} \mathrm{O}_{3}\right)$ of beach sands of the Barton and Weaver peninsulas, King George Island, West Antarctica (diagram after Pettijohn et al., 1972).

Table 3 shows the REE composition of studied beach sands. The beach sand samples of the Weaver Peninsula have $\sum$ REE contents ranging from 73.9 to $101.2 \mathrm{ppm}$ (median: $93.7 \mathrm{ppm}$ ), Eu anomaly (Eu/Eu*) from 0.88 to 0.95 (median: 0.92 ), and $(\mathrm{La} / \mathrm{Yb})_{\mathrm{N}}$ from 4.81 to 5.83 (median: 5.66). The beach sand samples of the Barton Peninsula have $\sum$ REE contents ranging from 95.7 to $132.8 \mathrm{ppm}$ (median: $108 \mathrm{ppm}$ ), $\mathrm{Eu} / \mathrm{Eu}^{*}$ from 0.77 to 0.88 (median: 0.86 ), and $(\mathrm{La} / \mathrm{Yb})_{\mathrm{N}}$ from 4.24 to 7.48 (median: 5.55). The $\sum$ REE content of Barton Peninsula beach sand sediments is slightly higher than that of the Weaver Peninsula beach sand sediments, whereas the former has a slightly larger negative $\mathrm{Eu} /$

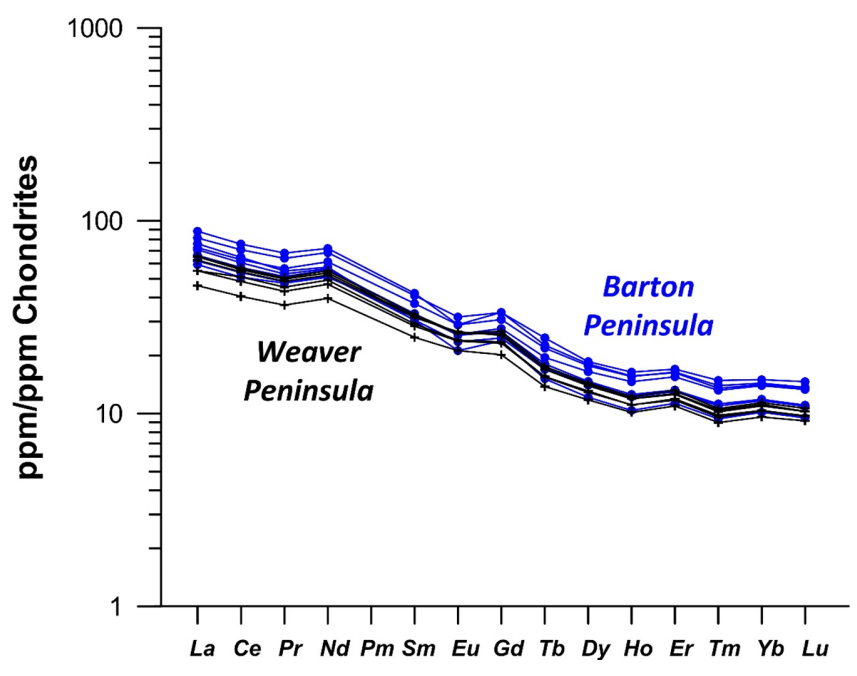

Fig. 5. Chondrite-normalized rare earth element patterns. Chondrite normalization values are from McDonough and Sun (1995).

$\mathrm{Eu}^{*}$ anomaly value that the latter, indicating that there is a statistically significant difference in $\mathrm{Eu} / \mathrm{Eu}^{*}(p=<0.001)$ and $\sum \mathrm{REE}$ content $(p=$ 0.007 ) of beach sand samples between them. The distribution pattern of chondrite-normalized REE is shown in Fig. 5. On the whole, the $(\mathrm{La} / \mathrm{Yb})_{\mathrm{N}}$ does not show a statistically significant difference $(p=$ 0.695) in the distribution of REE between the Weber and Barton peninsulas beach sand samples. The $(\mathrm{La} / \mathrm{Yb})_{\mathrm{N}}$ is less than 6 , indicating that the light rare earth elements were slightly more enriched than the heavy rare earth elements, exhibiting a relatively low degree of differentiation.

Table 3. Rare earth concentrations in ppm for beach sands from the Barton and Weaver peninsulas, King George Island, West Antarctica

\begin{tabular}{|c|c|c|c|c|c|c|c|c|c|c|c|c|c|c|c|c|c|}
\hline Sample & $\mathrm{La}$ & $\mathrm{Ce}$ & $\mathrm{Pr}$ & $\mathrm{Nd}$ & $\mathrm{Sm}$ & $\mathrm{Eu}$ & $\mathrm{Gd}$ & $\mathrm{Tb}$ & $\mathrm{Dy}$ & $\mathrm{Ho}$ & $\mathrm{Er}$ & $\mathrm{Tm}$ & $\mathrm{Yb}$ & $\mathrm{Lu}$ & $\mathrm{Sum}$ & $\mathrm{Eu} / \mathrm{Eu}$ & $(\mathrm{La} / \mathrm{Yb})_{\mathrm{N}}$ \\
\hline Weaver Peninsula & \multicolumn{10}{|c|}{} \\
\hline $04-01$ & 13.8 & 31.3 & 4.2 & 22.5 & 4.3 & 1.4 & 4.7 & 0.6 & 3.2 & 0.6 & 1.9 & 0.2 & 1.7 & 0.2 & 90.7 & 0.92 & 5.62 \\
\hline $04-02$ & 10.9 & 24.8 & 3.4 & 18.1 & 3.7 & 1.2 & 4.0 & 0.5 & 2.9 & 0.6 & 1.8 & 0.2 & 1.5 & 0.2 & 73.9 & 0.95 & 4.81 \\
\hline $04-03$ & 13.0 & 29.7 & 4.0 & 21.4 & 4.2 & 1.3 & 4.6 & 0.6 & 3.2 & 0.6 & 1.9 & 0.2 & 1.7 & 0.2 & 86.7 & 0.93 & 5.33 \\
\hline $04-17$ & 15.5 & 34.9 & 4.7 & 25.2 & 4.8 & 1.5 & 5.3 & 0.6 & 3.6 & 0.7 & 2.1 & 0.3 & 1.8 & 0.3 & 101.2 & 0.88 & 5.74 \\
\hline $04-18$ & 15.4 & 34.2 & 4.6 & 24.5 & 4.7 & 1.5 & 5.1 & 0.6 & 3.5 & 0.7 & 2.0 & 0.3 & 1.8 & 0.3 & 99.2 & 0.91 & 5.83 \\
\hline $04-19$ & 14.8 & 33.3 & 4.5 & 23.9 & 4.7 & 1.5 & 5.1 & 0.6 & 3.4 & 0.7 & 2.0 & 0.3 & 1.8 & 0.3 & 96.7 & 0.94 & 5.70 \\
\hline median & 14.3 & 32.3 & 4.4 & 23.2 & 4.5 & 1.4 & 4.9 & 0.6 & 3.3 & 0.6 & 2.0 & 0.2 & 1.7 & 0.2 & 93.7 & 0.92 & 5.66 \\
\hline Barton Peninsuala & & & & & & & & & & \\
\hline $30-23$ & 18.0 & 39.7 & 5.1 & 26.3 & 4.5 & 1.2 & 4.7 & 0.5 & 3.0 & 0.6 & 1.8 & 0.2 & 1.6 & 0.2 & 107.5 & 0.79 & 7.48 \\
\hline $28-02$ & 19.3 & 43.4 & 5.9 & 31.3 & 6.1 & 1.8 & 6.7 & 0.9 & 4.6 & 0.9 & 2.7 & 0.4 & 2.4 & 0.4 & 126.6 & 0.86 & 5.43 \\
\hline $29-05$ & 15.7 & 35.1 & 4.8 & 25.4 & 4.9 & 1.4 & 5.3 & 0.7 & 3.6 & 0.7 & 2.1 & 0.3 & 1.9 & 0.3 & 102.1 & 0.86 & 5.65 \\
\hline $31-28$ & 14.7 & 33.1 & 4.5 & 23.6 & 4.5 & 1.3 & 4.9 & 0.6 & 3.5 & 0.7 & 2.1 & 0.3 & 1.9 & 0.3 & 95.9 & 0.86 & 5.31 \\
\hline $31-34$ & 16.8 & 37.1 & 4.9 & 25.8 & 4.8 & 1.4 & 5.3 & 0.6 & 3.5 & 0.7 & 2.1 & 0.3 & 1.9 & 0.3 & 105.5 & 0.88 & 5.97 \\
\hline $28-03$ & 17.2 & 38.5 & 5.3 & 28.0 & 5.5 & 1.6 & 6.1 & 0.8 & 4.4 & 0.9 & 2.6 & 0.3 & 2.3 & 0.3 & 113.9 & 0.85 & 5.05 \\
\hline $29-15$ & 14.0 & 31.3 & 4.4 & 23.3 & 4.8 & 1.5 & 5.5 & 0.7 & 4.1 & 0.8 & 2.5 & 0.3 & 2.2 & 0.3 & 95.7 & 0.86 & 4.24 \\
\hline $29-09$ & 20.9 & 46.4 & 6.3 & 32.9 & 6.2 & 1.6 & 6.7 & 0.8 & 4.5 & 0.9 & 2.6 & 0.3 & 2.3 & 0.3 & 132.8 & 0.77 & 6.24 \\
\hline median & 17.0 & 37.8 & 5.0 & 26.0 & 4.9 & 1.4 & 5.4 & 0.7 & 3.8 & 0.7 & 2.3 & 0.3 & 2.1 & 0.3 & 108 & 0.86 & 5.55 \\
\hline
\end{tabular}




\section{Discussion}

\section{Perspectives from Petrography and Geochemistry}

\section{Source-rock weathering}

If chemical weathering of the bedrock had been active, the composition of the sand sediment of a certain size would not be considered to represent the composition of source rock. If chemical weathering occurs to some extent, among the minerals making up source rocks plagioclase will be preferentially affected first, followed by K-feldspar and quartz in that order. When the feldspar is weathered, it is converted into clay minerals, which will be accumulated as mud sediments. The chemical composition of the clastic sediments is known to provide valuable information on weathering conditions in the source (Jafarzadeh et al., 2014; Liu et al., 2016). Therefore, before attempting to infer the provenance of sand sediments, we will first examine the degree of weathering of the sediments.

The chemical index of alteration (CIA) proposed by Nesbitt and Young (1982) is widely used as an index to quantitatively estimate the degree of weathering in the source area. Using the CIA index, it is possible to measure to what extent feldspars have been altered to clay minerals (Selvaraj and Chen, 2006; Selvaraj et al., 2010, 2016). The CIA value is expressed by the formula CIA $=\left[\mathrm{Al}_{2} \mathrm{O}_{3} /\left(\mathrm{Al}_{2} \mathrm{O}_{3}+\mathrm{CaO} *\right.\right.$ $\left.\left.+\mathrm{Na}_{2} \mathrm{O}+\mathrm{K}_{2} \mathrm{O}\right)\right] \times 100$ using the molar ratio. Here, $\mathrm{CaO}^{*}$ refers to the content of $\mathrm{CaO}$ residing only in silicate minerals. The sand sediments of this study are Ca-bearing mineral cement-free and there is no evidence of calcite replacement of sand grains. In addition, there occur abundant intermediate-mafic volcanic rock fragments that are most susceptible to chemical weathering. All these observations lead us to conclude that the measured $\mathrm{CaO}$ is contained in the silicate mineral. According to Nesbitt and Young (1982), the CIA values of fresh plagioclase and K-feldspar are approximately 50 . Higher CIA values indicate that chemical weathering has occurred. However, in some studies, the CIA reflects changes in global conditions such as temperature, latitude, and runoff, and therefore requires caution when used as a quantitative indicator of the degree of chemical weathering on the continent (Li and Yang, 2010; Meunier et al., 2013; Zhou et al., 2015).

The CIA values of the studied beach sand samples of the Weber and Barton peninsulas range from 51.6 to 54.1 (median: 51.9) and 47.1 to 63.2 (median, 51.7), respectively. The difference in the CIA values of beach sand samples between the two peninsulas is not statistically significant $(p=0.484)$.

Because the calculated CIA median is close to 50, it is interpreted that chemical weathering at the source has hardly occurred.

The degree of chemical weathering of source rocks can be also inferred from plagioclase index of alteration (PIA; Fedo et al., 1995). The PIA value is calculated as PIA $=\left[\left(\mathrm{Al}_{2} \mathrm{O}_{3}-\mathrm{K}_{2} \mathrm{O}\right) /\left(\mathrm{Al}_{2} \mathrm{O}_{3}+\mathrm{CaO} *+\right.\right.$ $\left.\left.\mathrm{Na}_{2} \mathrm{O}\right)\right] \times 100$, where $\mathrm{CaO}^{*}$ indicates the content of $\mathrm{CaO}$ in the silicate as in the above CIA. The fresh plagioclase has a value of $\sim 50$, and if the weathering progresses, the value of PIA gradually increases. The PIA values of beach sand samples from the Weaver and Barton peninsulas are 49.5 to 52.5 (median: 50.8 ) and 46.2 to 60.3 (median: 49.7), respectively. There is no statistically significant difference $(p=0.287)$ between them. It is interpreted that very low occurrence of both glassy volcanic rock fragment (Choi et al., 2003) and sedimentary rock fragment may account for very low CIA and PIA values. Given the very low CIA and PIA values, chemical weathering at the source is considered to be rare and the environmental conditions of the source region would have been relatively cold and dry, as well as having relatively high relief (McLennan et al., 1993).

For reference, the median CIA values of the granodiorite, basaltic andesite-andesite, lapilli tuff, and Sejong Formation of the Barton Peninsula are 46.9, 45.8-46.1, 58.3, and 60.7, respectively (Lee et al., 2004). As the CIA values of the beach sand samples of the Barton and Weaver peninsulas are slightly higher than the CIA values of Barton Peninsula bedrocks except for the lapilli tuff and the Sejong Formation, the studied beach sand samples were derived from bedrocks experienced very little chemical weathering. The CIA value of the fine-grained surface material of the Barton Peninsula was calculated to be 59.2 (Lee et al., 2004), indicating that a weaker chemical weathering signature is registered in the studied beach sand samples. Therefore, it can be considered that the petrological and geochemical characteristics of the studied beach sand samples reflect the characteristics of their source rocks.

\section{Provenance}

It is interpreted that volcanic rock was the main source rock of the studied beach sand samples because the most abundant component of the sand samples is volcanic rock fragment $(>88 \%$ of the framework grains). Most of the volcanic rock fragments are of the lathwork type, and this texture is frequently observed in intermediate-mafic volcanic rocks (Dickinson, 1970). This interpretation is supported by the fact that almost all of the feldspar grain is composed of plagioclase although the feldspar content is less than $10 \%$ of the framework grains. Dickinson (1970) reported that feldspar grains derived from volcanic areas indicate that the plagioclase/total feldspar ratio is 0.75 to 1.00 .

The major element content and their elemental ratio are often used to characterize the provenance (Purevjav and Roser, 2013; ArmstrongAltrin et al., 2015a, b). The ratio of $\mathrm{Al}_{2} \mathrm{O}_{3} / \mathrm{TiO}_{2}$ in clastic sediments is considered to be a good indicator of source rock, which rises gradually from mafic to intermediate, and to acidic igneous rocks (Girty et al., 1996; Hayashi et al., 1997). According to Hayashi et al. (1997), $\mathrm{Al}_{2} \mathrm{O}_{3}$ is mostly contained in feldspar in igneous rocks, and $\mathrm{TiO}_{2}$ is contained in mafic minerals such as olivine, pyroxene, and ilmenite. The ratio of $\mathrm{Al}_{2} \mathrm{O}_{3} / \mathrm{TiO}_{2}$ is $\sim 3-8$ in mafic rock, $\sim 8-20$ in intermediate rock, and $\sim 21-70$ in acidic rock. In this study, the $\mathrm{Al}_{2} \mathrm{O}_{3} / \mathrm{TiO}_{2}$ ratio of the beach sand samples of the Weaver Peninsula is 21.4-25.6, while that of the beach sand samples in the northwestern beach of the Barton Peninsula is in the range of 21.3-27.2, and that of the beach sand samples of the southwestern, southern, and southeastern beaches has a relatively low range of 11.9-22.1. Based on the ratio of $\mathrm{Al}_{2} \mathrm{O}_{3} / \mathrm{TiO}_{2}$, the northwestern beach sand samples of the Barton Peninsula and the Weaver Peninsula beach sand samples are interpreted to have been derived from acidic source rocks, whose composition is close to the intermediate composition, whereas those of the southwestern, southern, and southeastern beaches of the Barton Peninsula are interpreted to have been derived from intermediate source rocks. This difference in source rocks can be explained by the differences in the constituent particles of beach sand sediments. The beach sand samples from the Weaver Peninsula 
and from the Barton Peninsula northwestern beach have higher contents of plutonic rock fragment and plagioclase than those from other beaches of the Barton Peninsula, which show higher contents of volcanic rock fragment derived from basaltic andesite and andesite than the former.

The distribution patterns of REE and $\mathrm{Eu}$ anomalies are also frequently used to study the provenance of clastic sediments because they are good indicators to distinguish between mafic and acidic rocks (Cullers, 1994; Kasper-Zubillaga et al., 2008; Etemad-Saeed et al., 2015; Lee et al., 2014; Zhang and Gao, 2015). As the beach sand samples from the Barton and Weaver peninsulas show similar $(\mathrm{La} / \mathrm{Yb})_{\mathrm{N}}$ to intermediate rocks (Condie, 1993), and similar $\mathrm{Eu} / \mathrm{Eu}^{*}$ to sediments derived from mafic rocks $\left(\mathrm{Eu} / \mathrm{Eu}^{*}=0.71-0.95\right.$; Cullers, 1994, 2000; Cullers and Podkovyrov, 2000), the studied beach sand sediments of the two peninsulas are interpreted to have been derived from intermediate to mafic rocks.

Source rock composition has been inferred using the $\mathrm{A}-\mathrm{CN}-\mathrm{K}$ $\left[\mathrm{Al}_{2} \mathrm{O}_{3}-\left(\mathrm{CaO}+\mathrm{Na}_{2} \mathrm{O}\right)-\mathrm{K}_{2} \mathrm{O}\right)$ plot for the change of whole-rock composition centered on the alteration of feldspar and the A-CNK-FM $\left[\mathrm{Al}_{2} \mathrm{O}_{3}-\left(\mathrm{CaO}^{*}+\mathrm{Na}_{2} \mathrm{O}+\mathrm{K}_{2} \mathrm{O}\right)-\left(\mathrm{Fe}_{2} \mathrm{O}_{3}+\mathrm{MgO}\right)\right]$ plot for the change of whole-rock composition centered on the change of leucocratic and melanocratic materials. In Fig. 6, most of the sand samples are found to be the closest composition to andesite and basalt. The $\mathrm{A}-\mathrm{CN}-\mathrm{K}$ plot is based on the molar ratios of $\mathrm{Al}_{2} \mathrm{O}_{3}, \mathrm{CaO}^{*}+\mathrm{Na}_{2} \mathrm{O}$, and $\mathrm{K}_{2} \mathrm{O}$. Plagioclase $(\mathrm{Pl})$ is located at $50 \%$ of $\mathrm{Al}_{2} \mathrm{O}_{3}$ on the left side of this triangle and $\mathrm{K}$-feldspar at $50 \% \mathrm{Al}_{2} \mathrm{O}_{3}$ on the right side of this triangle. The line connecting these two points is called 'feldspar join'. The individual beach sand samples of the Barton and Weaver peninsulas plot near the feldspar join. They plot close to the plagioclase composition. If the ladder rule is applied, the composition of the studied beach sand sediments is considered to contain $90 \%$ plagioclase. This indicates that the beach sand composition of the two peninsulas is interpreted to be mainly composed of grains derived from basaltic andesite to andesite with minor grains from granodiorite. This interpretation is further supported by the following observation. As shown in Fig. 6, two dotted rays extending from the A-apex through the most weathered sand and the least weathered sand intersect the plagioclase-K-feldspar tie line, reflecting the studied beach sands spread from the cluster of unweathered granodiorite and basaltic andesite specimens analyzed from the Barton Peninsula. This relationship indicates that coarse-grained beach sand samples are composed of little to weakly weathered detritus, and therefore, are likely derived mostly from physical weathering.

As the studied beach sand samples from both peninsulas are mostly composed of volcanic rock fragments, the type of volcanic rocks can be inferred using the chemical composition of the beach sands. Based on the diagram using the ratio of $\mathrm{SiO}_{2}$ and $\mathrm{Na}_{2} \mathrm{O}+\mathrm{K}_{2} \mathrm{O}$, the source volcanic rock for the Weaver Peninsula beach sand samples seemed andesite-dacite, for the northwestern beach sand samples of the Barton Peninsula seemed dacite, for the western, southwestern and southern beach sand samples of the Barton Peninsula seemed andesite, and for the southeastern beach sand samples of the Barton Peninsula seemed dacite (Fig. 7).

Based on the above volcanic rock fragment texture and geochemistry, it is interpreted that the source rocks of the beach sand samples of both

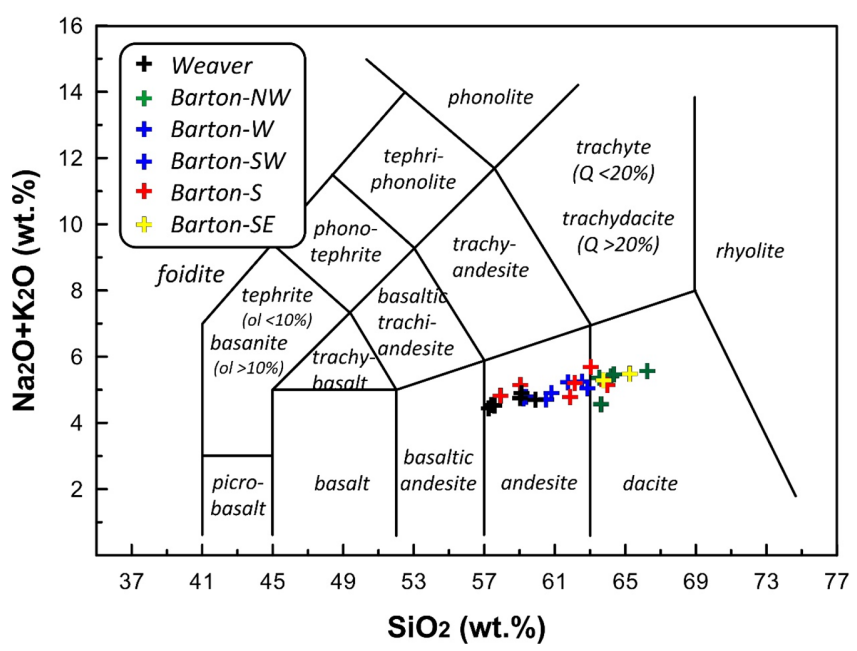

Fig. 7. Total alkali versus silica classification scheme of volcanic rocks (after Le Bas et al., 1986).

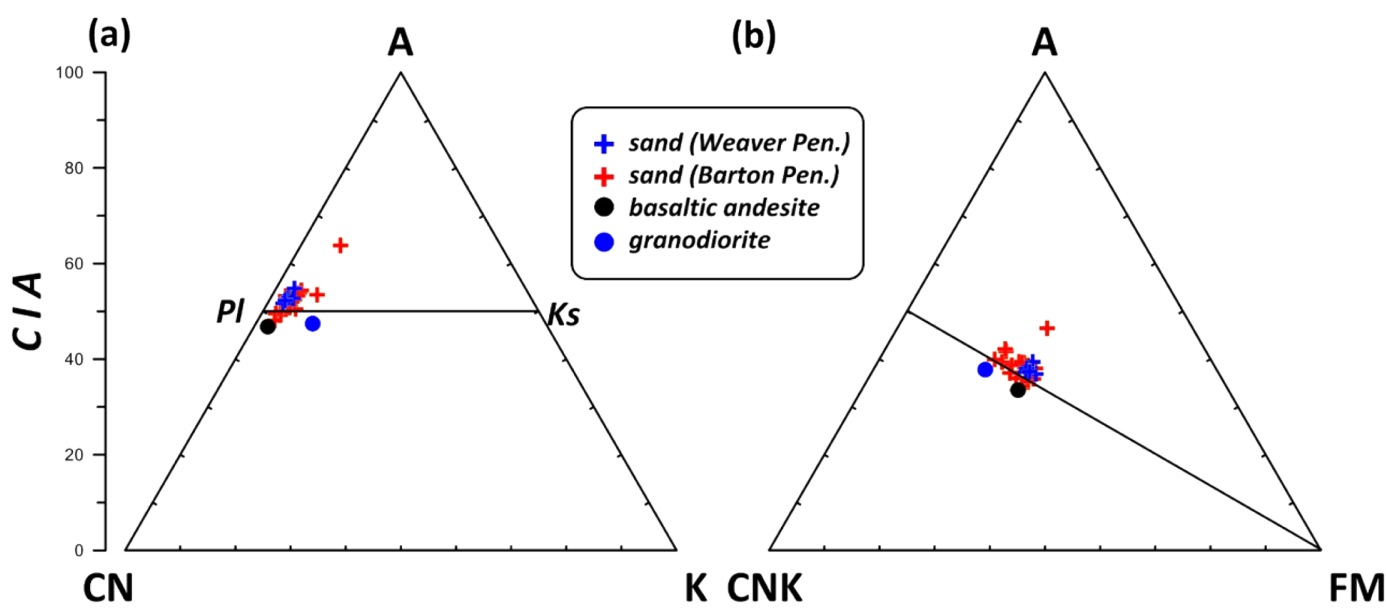

Fig. 6. (a) $\mathrm{Al}_{2} \mathrm{O}_{3}-\left(\mathrm{CaO}+\mathrm{Na}_{2} \mathrm{O}\right)-\mathrm{K}_{2} \mathrm{O}$ and (b) $\mathrm{Al}_{2} \mathrm{O}_{3}-\left(\mathrm{CaO}+\mathrm{Na}_{2} \mathrm{O}+\mathrm{K}_{2} \mathrm{O}\right)-\left(\mathrm{Fe}_{2} \mathrm{O}_{3}+\mathrm{MgO}\right)$ triangle (molar proportions). The relation between the CIA scale (Nesbitt and Young, 1982) and the triangles is shown on the left side of the diagram. The average compositions of representative granodiorite (Lee et al., 2001) and basaltic andesite (Yeo et al., 2004) are plotted on (a). Abbrevations: $\mathrm{A}=\mathrm{Al}_{2} \mathrm{O}_{3} ; \mathrm{CN}=\mathrm{CaO}+\mathrm{Na} \mathrm{O}_{2}$; $\mathrm{K}=$ $\mathrm{K}_{2} \mathrm{O} ; \mathrm{CNK}=\mathrm{CaO}+\mathrm{Na}_{2} \mathrm{O}+\mathrm{K}_{2} \mathrm{O} ; \mathrm{FM}=\mathrm{Fe}_{2} \mathrm{O}_{3}+\mathrm{MgO} ; \mathrm{IL}=$ illite; $\mathrm{Mu}=$ muscovite; $\mathrm{Pl}=$ plagioclase; $\mathrm{Ks}=$ alkali feldspar; $\mathrm{Fs}=$ feldspars; $\mathrm{Ka}$ = kaolinite; $\mathrm{Gi}=$ gibbsite; $\mathrm{Bi}=$ biotite; $\mathrm{Gt}=$ garnet. 
peninsulas were mostly intermediate volcanic rocks, probably andesite.

\section{Tectonic setting}

Based on the constituent particles of the beach sand samples, the source tectonic setting is interpreted to be the undissected-arc setting (Fig. 3) when plotted on the ternary diagram of Dickinson (1985). This interpretation is supported by the results of the tectonic setting discrimination using geochemical composition of sediments. Using the major elemental composition of the sediments, Verma and ArmstrongAltrin (2013) divided the clastic sediments into high silica and low silica groups and proposed two multi-dimensional diagrams for discrimination of tectonic setting. The classification of the clastic sediments by the silicon dioxide content is based on the recalculated volatilefree silicon dioxide content (referred to as the adjusted silicon dioxide content) of the sediments. When the adjusted silicon dioxide content is between $63 \%$ and $95 \%$, the sediment belongs to the high silicon dioxide group, whereas the low silicon dioxide group sediments are defined when the adjusted silicon dioxide content is between $35 \%$ and $63 \%$. These multidimensional diagrams have been well applied in recent studies to infer the tectonic setting of clastic sediments (ArmstrongAltrin, 2015; Armstrong-Altrin et al., 2014, 2015a; Zaid and Gahtani, 2015). In this study, six sand samples from the northwestern beach, and two samples from the southeastern (2) beach and one sample from the southern beach of the Barton Peninsula belong to the high $\mathrm{SiO}_{2}$ group, and all sand samples from the Weaver Peninsula (6) and five sand samples from the northwestern, two samples from the southwestern beach, and five sand samples in the southern beach of the Barton Peninsula corresponded to the low $\mathrm{SiO}_{2}$ group. In the multi-dimensional diagrams (Fig. 8) of Verma and Armstrong-Altrin, regardless of the $\mathrm{SiO}_{2}$ content all the studied beach sand samples plot in the volcanic arc field.

\section{Comparison Between Provenance Interpretation and the Geology of the Barton and Weaver Peninsulas}

In the modal composition, the constituent particles of the studied beach sand samples were observed in abundance in the order of volca- nic rock fragment, altered grains, and plutonic rock fragment. According to the provenance interpretation based on the modal composition of the beach sand samples of the Barton and Weaver peninsulas, the bedrock of the King George Island seems to be composed of volcanic rocks, altered volcanic rocks, plutonic rocks, and minor sedimentary rocks in that order. Based on the geochemical composition of the beach sand samples, the source rocks for the Weaver peninsula and the northwestern beach of the Barton Peninsula were acidic-intermediate rocks formed in the volcanic arc environments, and for the southwestern to southern beaches of the Barton Peninsula were mainly intermediate rocks also in the volcanic arc environments. The intermediate rocks are inferred to be andesite and basaltic andesite. The information about the provenance and tectonic setting inferred from petrography and geochemistry is in close agreement with the current bedrock geology and tectonic setting of King George Island. Thus, this study supports previous researches that provenance can be interpreted using modal composition and geochemical composition of siliciclastic sediments.

Based on the geology of the ice-free areas of the Barton and Weaver peninsulas, most of the rock fragments in the beach sand sediments are interpreted to have been derived from basaltic andesite-andesite, granodiorite, and altered rocks. However, if we look more closely, there exist some regional differences in modal composition between the two groups of beach sands. The modal composition of the sands of the Weaver Peninsula beach and the northwestern beach of the Barton Peninsula differs from that of the southwestern to southeastern beaches of the Barton Peninsula. Besides the volcanic rock fragment, the former beach sands are relatively rich in plagioclase and plutonic rock fragment with relatively high content of sedimentary rock fragment and quartz. On the other hand, the latter beach sands contain abundant volcanic rock fragment and altered grains but very low quartz and plagioclase content. In the case of heavy minerals and other components, their content is very low and thus there is no obvious trend.

Volcanic rock fragment of the beach sands of the Barton Peninsula can be interpreted to have originated from the widely distributed volcanic rocks in the ice-free areas of the peninsula. However, in the case of the Weaver Peninsula, most of the ice-free areas are composed of the Sejong Formation, and the volcanic rock is distributed less than 1/
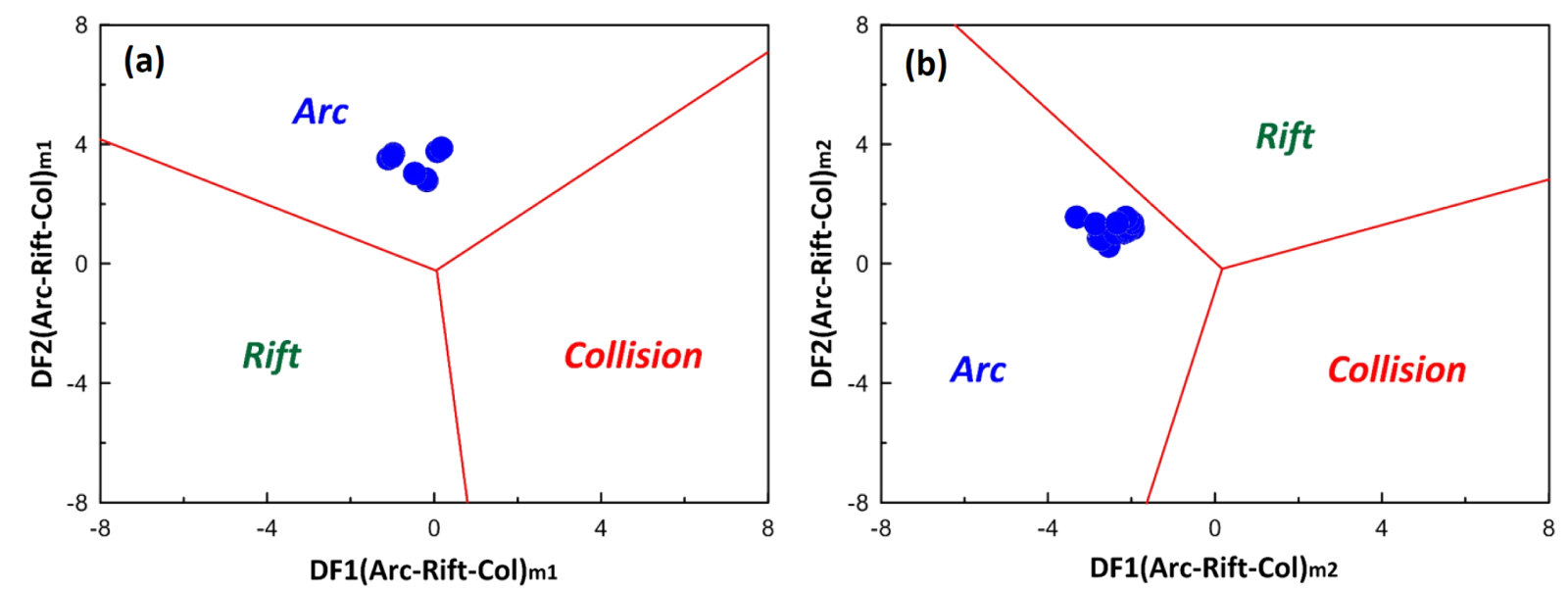

Fig. 8. Plot of beach sand samples from the Weaver and Barton peninsulas in discriminant-function multidimensional diagrams for (a) lowsilica and (b) high-silica clastic sediments (after Verma and Armstrong-Altrin, 2013). The subscript m1 in DF1 and DF2 represents the highsilica and low-silica diagrams based on loge ratios of major elements. 
7 of the ice-free area. The median value of volcanic rock fragment in the Weaver Peninsula beach sands accounts for $61 \%$ of the framework grains, making it difficult to interpret that the observed volcanic rock fragments were derived from such small volcanic rock outcrops exposed in the ice-free area on the peninsula. The volcanic rock fragments of the Weaver Peninsula beach sands were probably derived from fresh and altered volcanic rocks that might have been distributed in a much larger area than they are now, suggesting that they were derived from volcanic rocks underneath Sejong Ice Cap.

The bedrocks distributed in the Barton Peninsula have undergone extensive hydrothermal alteration due to the intrusion of granodiorite. The degree of alteration is higher in the north of the granodiorite pluton in the ice-free areas and is predominated by the sericitization and silicification (Hwang, 1998; Hur et al., 2001). However, the altered grain content in the southwestern and southeastern beaches is higher than that in the northwestern beach. Considering that the hydrothermally altered rocks are mainly distributed in the northwestern part of the Barton Peninsula, this observation suggests that the distribution of altered grains in the southern beaches were not derived from the altered bedrock distributed in ice-free areas of the Barton Peninsula, but were transported by southward-flowing Sejong Ice Cap from the altered volcanic rocks underneath it.

According to the geological map, source rocks that can provide plutonic rock fragment, plagioclase, and quartz grains in the studied beach sands is likely to be granodiorite distributed in the northwestern part of the Barton Peninsula. The sand samples from the northwestern beach of the Barton Peninsula are characterized by high proportion of plutonic rock fragment, plagioclase, and quartz grains and their content decreases drastically to the southwestern, southern, and southeastern beaches in that order. Accordingly, these grains were likely to have been derived from granodiorite exposed in the nearby ice-free areas. This interpretation is supported by westward glacial flows on the Barton Peninsula with some toward south in the southeastern part inferred from striations formed on surface of the roche moutonnees (Seong et al., 2009). However, it is difficult to argue that those sands of the Weaver Peninsula beach and the southern beaches of the Barton Peninsula were derived from the nearby basement rocks currently exposed in the ice-free areas of the two peninsulas. On the Weaver Peninsula the Sejong Formation is mainly distributed with small distribution of volcanic rocks and diorite and in the southern Barton Peninsula volcanic rocks are mainly distributed in the nearby ice-free areas. Other than the granodiorite pluton of the Barton Peninsula, the probable source of these acidic-intermediate pluton-derived grains could be the northern coast of the Antarctic Peninsula where crystalline rocks are distributed (Choi et al., 2003). However, the possibility of sand transport from this area to the studied beaches is very unlikely because these grains have to be transported across the deep Bransfield Strait locating between King George Island and the Antarctic Peninsula.

Sejong Ice Cap draining into Marian Cove deliver icebergs during the summer months (Yoon et al., 1998). Considering that at present granodiorite on the northwestern Barton Peninsula seems the only source rock for plutonic rock fragment, plagioclase, and quartz grains, it is interpreted that these grains were supplied from the granodiorite when it was exposed due to the retreat of Sejong Ice Cap. Since then icebergs calved from the northwestern coast of the Barton Peninsula where granodiorite is distributed were drifting along the coast due to the influence of predominant winds and supplied these granodiorite-derived components. As a cyclonic circulation is generated when the northwesterly is predominant, icebergs carrying granodiorite debris might have been drifted across the cove and then stayed long along the coast of the Weaver Peninsula where they dropped sediments when melting. After the front of the tidewater glacier retreated past the eastern end of the granodiorite body, shorefast sea ice that is attached to the granodiorite might have taken over the role of icebergs until today. This interpretation is supported by the occurrence of granodioritederived sand grains in the Weaver Peninsula more in the beach on the Marian Cove side than in the beach on the Maxwell Bay side. If this interpretation is accepted, the supply of granodiorite-derived sand grains to the present-day Weaver Peninsula beaches may have started in the mid-18th century or earlier considering the slower rate of ice cliff retreat than in recent years. The icebergs and sea ice are, however, generally small and depleted in clasts and thus it is less likely that these grains were supplied by icebergs and/or shorefast sea ice that were attached to the granodiorite on the northwestern Barton Peninsula.

Alternatively and more likely, plutonic rock fragment and plagioclase grains were derived from the Weaver Peninsula itself. Given the very low quartz grain content ( $\sim 3.4 \%$ of framework grains), these grains may have been derived from plutonic rocks with intermediate composition. Direction of glacial flows on the Weaver Peninsula was toward south (Seong et al., 2009), suggesting that these grains might have been transported by advancing Sejong Ice Cap. In addition to the small outcrop of diorite presently exposed in the Weaver Peninsula, plutonic rocks with intermediate composition are likely to be distributed under the glacier, following the same argument for the altered grains.

Raised beaches are common around the coasts of the Barton and Weaver peninsulas where several levels have been recognized with an elevation mostly ranging from 3 to $12 \mathrm{~m}$, with the highest raised beach at $54 \mathrm{~m}$ in elevation near the Winship Point located at the southeastern tip of the Barton Peninsula (Sugden and John, 1973). These raised beaches are thought to reflect local glacio-isostatic uplift as the ice cover thinned and withdrew. The oldest ages of raised beaches in Maxwell Bay are optically stimulated luminescence ages of 1.7-2.2 $\mathrm{ka}$ at an elevation of $11 \mathrm{~m}$ (Simms et al., 2011).

The presence of intermediate pluton-derived sand grains and hydrothermally-altered grains in the sand deposits of the Weaver Peninsula beaches and the southern beach of the Barton Peninsula provides a clue that these sand grains were not originated from bedrocks exposed on current ice-free areas of both peninsulas. Instead, these sand grains are interpreted to have been subaqueous moraines that were eroded from plutonic rocks and associated hydrothermally altered volcanic rocks that were present in the subglacial basement during glacial advance. The accumulation of these subaqueous moraines is believed to have occurred before the LGM or during the Neoglacial cold event of late Holocene. These subaqueous moraines became uplifted and exposed to the present beach environments due to the glacio-isostatic uplift of King George Island including the two peninsulas. Considering that the Marian Cove Glacier started to retreat around $1.7 \mathrm{ka}$ and Marian Cove began to open (Simms et al., 2011), it is likely that the present beach sediments of the Barton and Weaver peninsulas probably formed post $1.7 \mathrm{ka}$. 


\section{Conclusions}

The beach sand sediments of the Barton and Weber peninsulas were mainly derived from basement rocks distributed in the both icecovered and ice-free areas of the two peninsulas. The studied beach sand sediments of the both peninsulas are predominantly composed of volcanic-rock fragment, followed by altered grain and plutonic rock fragment in that order. These beach sands may have been originated from basaltic andesite-andesite distributed in the ice-free areas of the Barton and Weaver peninsulas and granodiorite of the Barton Peninsula. According to the geochemistry of the beach sand sediments of the two peninsulas, most of the sand samples are interpreted as originating from intermediate rocks that have experienced little chemical weathering. Taking together the modal composition and geochemical composition of the beach sand samples, the tectonic setting of the source area is interpreted as a magmatic arc setting. This interpretation is consistent with the geology and tectonic setting of King George Island at present. However, the sand samples of the southern beach of the Barton Peninsula and the Weaver Peninsula beach may not have been derived directly from basement rocks currently exposed in the ice-free area of the corresponding peninsula, but were subaqueous moraines derived from erosion of ice-covered subglacial basement rocks and transported to the submerged glacier grounding line prior to deglaciation. In addition, sand sediments derived from wave erosion of basement rocks of paleoshoreline may have been mixed with these moraines. After the deglaciation, King George Island became uplifted and the current coastline was formed and the studied beach sediments are interpreted as being reworked under the current conditions. Thus, the present beach sand sediments of the Barton and Weaver peninsulas were originally accumulated in the shallow fjord in Maxwell Bay and were uplifted, and thus are interpreted as palimpsest affected by waves and tides in the present beach environments.

\section{Acknowledgements}

This research was supported by the Korea Polar Research Institute (PE19030) for Y.I. Lee, and the Polar Academic Program (PE19900), KOPRI for H.S. Lim.

\section{References}

Araya, R., and Hervé, F., 1972, Periglacial phenomena in the South Shetland Islands. In: Adie, R.J. (Ed.), Antarctic Geology and Geophysics. International Union of Geological Sciences Oslo, Series B, 1. pp. 105-109

Armstrong-Altrin, J.S., Lee, Y.I., Kasper-Zubbillaga, J.J., Eby, G.N., Garcia, D., Carranza-Edwards, A., Balaram, V., and Cruz-Oriz, N.L., 2012, Geochemistry of beach sands along the western Gulf of Mexico, Mexico: Implications for provenance. Chemie der Erde/Geochemistry, v. 72 , pp. 345-362.

Armstrong-Altrin, J.S., Lee, Y.I., Kasper-Zubbillaga, J.J., and TrejoRamírez, E., 2017, Mineralogy and geochemistry of sands along the Manzanillo and El Carrizal beach areas, southern Mexico: implications for palaeoweathering, provenance and tectonic setting. Geological Journal, v. 52, pp. 559-582.
Armstrong-Altrin, J.S., 2015, Evaluation of two multidimensional discrimination diagrams from beach and deep-sea sediments from the Gulf of Mexico and their application to Precambrian clastic sedimentary rocks. International Geology Review, v. 57, pp. 1446-1461.

Armstrong-Altrin, J.S., Machan-Castillo, M.L., Rosales-Hoz, L., Carranza-Edwards, A., Sanchez-Cabeza, J.A., and Ruiz-Fernández, A.C., 2015a, Provenance and depositional history of continental slop sediments in the Southwestern Gulf of Mexico unraveled by geochemical analysis. Continental Shelf Research, v. 95, pp. 15-26.

Armstrong-Altrin, J.S., Nagarajan, R., Balaram, V., and Natalhy-Pineda, O., 2015b, Petrography and geochemistry of sands from the Chachalacas and Veracruz beach areas, western Gulf of Mexico, Mexico: constraints on provenance and tectonic setting. Journal of South American Earth Sciences, v. 64, pp. 199-216.

Armstrong-Altrin, J.S., Nagarajan, R., Lee, Y.I., Kasper-Zubillaga, J.J., and Córdoba-Salana, L.P., 2014, Geochemistry of sands along the San Nicolás and San Carlos beaches, Gulf of California, Mexico: implications for provenance and tectonic setting. Turkish Journal of Earth Sciences, v. 23, pp. 533-558.

Barnard, P.L., Foxgrover, A.C., Elias, E.P.L., Erikson, L.H., Hein, J.R., McGann, M., Mizell, K., Rosenbauer, R.J., Swarzenski, P.W., Takesue, R.K., Wong, F.L., and Woodrow, D.L., 2013, Integration of bed characteristics, geochemical tracers, current measurements, and numerical modeling for assessing the provenance of beach sand in the San Francisco Bay Coastal System. Marine Geology, v. 336, pp. 120-145.

Barsh, D., and Mäusbacher, R., 1986. New data on the relief development of the South Shetland Islands, Antarctica. Interdisciplinary Science Review, v. 11, pp. 211-219.

Bhatia, M.R., 1983, Plate tectonics and geochemical composition of sandstones. The Journal of Geology, 91, 611-627.

Carranza-Edwards, A., and Rosales-Hoz, L., 1995, Grain-size trends and provenance of southwestern Gulf of Mexico beach sands. Canadian Journal of Earth Sciences, v. 32, pp. 2009-2014.

Carranza-Edwards, A., Kasper-Zubillaga, J.J., Rosales-Hoz, L., Moralesde la Garza, E.A., and Lazano-Santa Cruz, R., 2009, Beach sand composition and provenance in a sector of the southwestern Mexican Pacific. Revista Mexicana de Ciencias Geológicas, v. 26, pp. 433-447.

Chang, S.-K., Lee, J.I., Choe, M.Y., and Hur, S.D., 2003, Geology around the King Sejong Station, King George Island off the Antarctic Peninsula. Journal of Geological Society of Korea, v. 39, pp. 271-286 (in Korean with English abstract).

Choi, T.J., Lee, Y.I., and Yoon, H.I., 2003, Characteristics of beach sands, King George Island, West Antarctica. Journal of Geological Society of Korea, v. 39, pp. 391-402 (in Korean).

Chung, H.S., Lee, B.Y., Chang, S.-K., and Kim, Y.D., 2004, Ice cliff retreat and sea-ice formation observed around King Sejong Station in King George Island, West Antarctica. Ocean and Polar Research, v. 26, pp. 1-10 (in Korean with English abstract).

Clemens, K.E., and Komar, P.D., 1988, Oregon beach-sand compositions produced by the mixing of sediments under a transgressing sea. Journal of Sedimentary Research, v. 58, pp. 519-529.

Condie, K.C., 1993, Chemical composition and evolution of the upper continental crust: Contrasting results from surface samples and shales. Chemical Geology, v. 104, pp. 1-37.

Cullers, R.L., and Podkovyrov, V.N., 2000, Geochemistry of the Mesoproterozoic Lakhanda shales in southeastern Yakutia, Russia: implications for mineralogical and provenance control, and recycling. Precambrian Research, v. 104, pp. 77-93.

Cullers, R.L., 1994, The controls on the major and trace element variation of shales, siltstones, and sandstones of Pennsylvanian-Permian age from uplifted continental blocks in Colorado to platform sediment in Kansas, USA. Geochimica et Cosmochimica Acta, v. 58, pp. 4955-4972.

Cullers, R.L., 2000, The geochemistry of shales, siltstones and sandstones of Pennsylvanian - Permian age, Colorado, U.S.A.: Implications for provenance and metamorphic studies. Lithos, v. 51, 181-203. 
Dickinson, W.R., 1970, Interpreting detrital modes of greywacke and arkose. Journal of Sedimentary Petrology, v. 40, pp. 695-707.

Dickinson, W.R., 1985, Interpreting provenance relations from detrital modes of sandstones. In: Zuffa, G.G. (Ed.), Provenance of Arenites. D. Reidel, Boston, pp. 333-361.

El-Anwar, A.E.A., and El-Wekeil, S.S., 2013, Contribution to the provenance and paleoclimate of the Lower Paleozoic sandstones of Naqua Formation, Wadi Qena, Northern eastern desert: integration of support petrography, mineralogy and geochemistry. Journal of Applied Sciences Research, v. 9, pp. 6529-6546.

Etemad-Saeed, N., Hosseini-Barzi, M., Adabi, M.H., Sadeghi, A., and Houshmandzadeh, A., 2015, Provenance of Neoproterozoic sedimentary basement of northern Iran, Kahar Formation. Journal of African Earth Sciences, v. 111, pp. 54-75.

Fedo, C.M., Nesbitt, H.W., and Young, G.M., 1995, Unraveling the effects of potassium metasomatism in sedimentary rocks and paleosols, with implications for paleoweathering conditions and provenance. Geology, v. 23, pp. 921-924.

Folk, R.L., 1974, Petrology of Sedimentary Rocks. Hemphill Publishing Company, Texas, $182 \mathrm{p}$.

Girty, G.H., Ridge, D.L., Knaack, C., Johnson, D., and Al-Riyami, R.K., 1996, Provenance and depositional setting of Paleozoic chert and argillite, Sierra Nevada, California. Journal of Sedimentary Research, v. 66, pp. 107-118.

Hayashi, K.-I., Fujisawa, H., Holland, H.D., and Ohmoto, H., 1997, Geochemistry of $\sim 1.9$ Ga sedimentary rocks from northeastern Labrador, Canada. Geochimica et Cosmochimica Acta, v. 61, pp. 4115-4137.

Hegde, V.S., Shalini, G., and Kanchanagouri, D.G., 2006, Provenance of heavy minerals with special reference to ilmenite of the Honnavar beach, central west coast of India. Current Science, v. 91, pp. 644-648.

Hur, S.D., Lee, J.I., Hwang, J., and Choe, M.Y., 2001, K-Ar age and geochemistry of hydrothermal alteration in the Barton Peninsula, King George Island, Antarctica. Ocean and Polar Research, v. 23, pp. 11-21.

Hwang, J., and Lee, J.I., 1998, Hydrothermal alteration and mineralization in the granodioritic stock of the Barton Peninsula, King George Island, Antarctica. Economic and Environmental Geology, v. 31, pp. 171-183.

Jafarzadeh, M., Harami, R.M., Amini, A., Mahboubi, A., and Farzaneh, F., 2014, Geochemical constraints on the provenance of Oligocene-Miocene siliciclastic deposits (Zivah Formation) of NW Iran: implications for the tectonic evolution of the Caucasus. Arabian Journal of Geosciences, v. 7, pp. 4245-4263.

Johnsson, M.J., and Basu, A.(Eds.), 1993. Processes controlling the composition of clastic sediments (Vol. 284). Geological Society of America, $342 \mathrm{p}$

Jin, M.-S., Lee, M.-S., Kang, P.-C., and Jwa, Y.-J., 1991, Petrology and geochemistry of the volcano-plutonic rocks in the Barton and Weaver Peninsula, King George Island, Antarctica. Korean Journal of Polar Research, v. 2, pp. 107-134

Jwa, Y.-J., Park, B.-K., and Kim, Y., 1992, Geochronology and geochemistry of the igneous rocks from Barton and Weaver peninsulas, King George Island: A review. In: Yoshida, Y., Kaminuma, K. and Shiraishi, K. (Eds.), Recent Progress in Antarctic Earth Science. Terra Scientific Publishing Company, Tokyo, pp. 439-442.

Kasper-Zubillaga, J.J., Acevedo-Vargas, B., Morton Bermea, O., and Ortiz-Zamora, G., 2008, Rare earth elements of the Altar desert dune and coastal sands, Northwestern Mexico. Chemie der Erde Geochemistry, v. 68 , pp. $45-59$.

Kim, H., Lee, J.I., Chose, M.Y., Cho, M., Zheng, X., Sang, H., and Qiu, J., 2000, Geochronologic evidence for early cretaceous volcanic activity on Barton Peninsula, King George Island, Antarctica. Polar Research, v. 19(2), pp. 251-260.

Klöser, H., Ferreyra, G., Schloss, I., Mercuri, G., Laturnus, F., and Curtosi, A., 1994, Hydrography of Potter Cove, a small fjord-like inlet on King George Island (South Shetland). Estuarine Coastal and Shelf Science, v. 38, pp. 523-537.

Koh, Y.-Y., Park, Y.-A., and Choe, M.Y., 1993, Analysis of beach gravels in Barton and Weaver Peninsulas, King George Island, Antarctica. Korean Journal of Polar Research, v. 4, pp. 39-51 (in Korean with English abstract).

Le Bas, M.J., Le Maitre, R.W., Streckeisen, A., and Zanettin, B., 1986, A chemical classification of volcanic rocks based on the total alkali-silica diagram. Journal of Petrology, v. 27, pp. 745-750.

Lee, D.-Y., 1992, Topographic evidences of raised beach along the Barton Peninsula, Antarctica. Korean Journal of Polar Research, v. 3, pp. 71-84 (in Korean with English abstract).

Lee, J.I., Hur, S.D., Yoo, C.M., Yeo, J.P., Kim, H., Hwang, J., Choe, M.Y., Nam, S.H., Kim, Y., Park, B.-K., Zheng, X., and López-Martínez, J., 2001, Explanatory text of the geological map of Barton and Weaver Peninsulas, King George Island, Antarctica (1:10,000). Korea Ocean Research and Development Institute, Ansan, $28 \mathrm{p}$.

Lee, J.I., Hwang, J., Kim, H., Kang, C.Y., Lee, M.J., and Nagao, K., 1996, Subvolcanic zoned granitic pluton in the Barton and Weaver peninsulas, King George Island, Antarctica. Proceedings of the NIPR Symposium on Antarctic Geosciences, v. 9, pp. 76-90.

Lee, J.I., Park, B.-K., Jwa, Y.-J., Yoon, H.I., Yoo, K.C., and Kim, Y., 2005, Geochemical characteristics and the provenance of sediments in the Bransfield Strait, West Antarctica. Marine Geology, v. 219, pp. 81-98.

Lee, M.K., Lee, S.H., Lee, Y.I., Yoon, H.I., and Yoo, K.-C., 2014, Rare earth element composition of paleo-maar sediments (latest Pleistocene-Early Holocene), Jeju Island, Korea: Implications for Asian dust record and monsoon climate. Quaternary International v. 344, pp. 32 42.

Lee, S.-G., Kim, J.-K., Yang, D.-Y., and Kim, J-Y., 2004, Provenance of the river sediments in Icheon area based on the grain sizes and their geochemical characteristics. Journal of Geological Society of Korea, v. 40, pp. 409-429 (in Korean with English abstract).

Lee, Y.I., Lim, H.S., and Yoon, H.I., 2004, Geochemistry of soils of King George Island, South Shetland Islands, West Antarctica: Implications for pedogenesis in cold polar regions. Geochemica et Cosmochimica Acta, v. 68, pp. 4319-4333.

Li, C., and Yang, S., 2010, Is chemical index of alteration (CIA) a reliable proxy for chemical weathering in global drainage basins? American Journal of Science, v. 310, pp. 111-127.

Lister, B., 1982, Evaluation of analytical data: a practical guide for geoanalysis. Geostandards Newsletter, v. 6, pp. 105-175.

Liu, B., Jin, H.-L., Sun, L.-Y., Sun, Z., Niu, Q.-H., and Zhang, C.-X., 2016, Geochemical characteristics of Holocene aeolian deposits and their environmental significance in the Mu Us desert, northern China. Geological Journal, v. 51, pp. 325-337.

López-Martínez, J., Serrano, E.,Schmid, T., Mink, S., and Linés, C., 2012, Periglacial processes and landforms in the South Shetland Islands (northern Antarctic Peninsula region). Geomorphology, v. 155-156, pp. 62-79.

Loring, D.H., and Asmund, G., 1996, Geochemical factors controlling accumulation of major and trace elements in Greenland coastal and fjord sediments. Environmental Geology, v. 28, pp. 1-11.

Madhavaraju, J., and Ramasamy, S., 2001, Clay mineral assemblages and rare earth element distribution in the sediments of Ariyalur Group, Tiruchirapalli District, Tamil Nadu-implication for Paleoclimate. Journal of the Geological Society of India, v. 58, pp. 69-77.

Madhavaraju, J., González-León, C.M., Lee, Y.I., Armstrong-Altrin, J. S., and Reyes-Campero, L.M., 2010, Geochemistry of the Mural Formation (Aptian-Albian) of the Bisbee Group, Northern Sonora, Mexico. Cretaceous Research, v. 31, pp. 400-414.

McDonough, W.F., and Sun, S.-s., 1995, The composition of the Earth. Chemical Geology, v. 120, pp. 223-253.

McLennan, S.M., Hemming, S., McDaniel, D.K. and Hanson, G.N., 1993, Geochemical approaches to sedimentation, provenance, and tectonics. In: Johnsson, M.J., and Basu, A. (Eds.), Processes Controlling the Compo- 
sition of Clastic Sediments. Geological Society of America Special Paper, pp. 21-40.

Meunier, A., Caner, L., Hubert, F., Albani, A.E., and Prêt, D., 2013, The weathering intensity scale (WIS): an alternative approach of the chemical index of alteration (CIA). American Journal of Science, v. 313, pp. 113-143.

Morrone, C., De Rosa, R., Le Pera, E., and Marsaglia, K.M., 2017, Provenance of volcanicalstic beach sand in a magmatic-arc setting: an example from Lipari Island (Aeolian archipelago, Tyrrhenian Sea). Geological Magazine, v. 154, pp. 804-828.

Nesbitt, H.S., and Young, G.M., 1982, Early Proterozoic climates and plate motions inferred from major element chemistry of lutites. Nature, v. 299 , pp. $715-717$

Nesbitt, H.W., and Young, G.M, 1989, Formation and diagenesis of weathering profiles. Journal of Geology, v. 97, pp. 129-147

Nesbitt, H.W., and Young, G.M., 1996, Petorogenesis of sediments in the absence of chemical weathering: effects of abrasion and sorting on bulk composition and mineralogy. Sedimentology, v. 43, pp. 341-358.

Park, B.-K., 1989, Potassium-argon radiometric ages of volcanic and plutonic rocks from the Barton Peninsula, King George Island, Antarctica. Journal of Geological Society of Korea, v. 25, pp. 495-497 (in Korean with English abstract).

Park, M.-E., 1991, Epithermal alteration and mineralization zoning within the stratovolcano, Barton Peninsula, King George Island. Korean Journal of Polar Research, v. 2, pp. 141-154 (in Korean with English abstract).

Pettijohn, F.J., Potter, P.E., and Siever, R., 1972, Sand and Sandstones. Springer-Verlag, New York, $618 \mathrm{p}$.

Purevjav, N., and Roser, B., 2013, Geochemistry of Silurian-Carboniferous sedimentary rocks of the Ulaanbaatar terrane, Hangay-Hentey belt, central Mongolia: provenance, paleoweathering, tectonic setting, and relationship with the neighbouring Tsetserleg terrane. Chemie der Erde Geochemistry, v. 73, pp. 481-493.

Qiu, S., Zhu, Z., Yang, T., Wu, Y., Bai, Y., and Ouyang, T., 2014, Chemical weathering of monsoonal eastern China: implications from major elements of topsoil. Journal of Asian Earth Sciences, v. 81, pp. 77-90.

Rock, N.M.S., Webb, J.A., McNaughton, N.J., and Bell, G.D., 1987. Nonparametric estimation of averages and errors for small data sets in isotope geoscience: a proposal. Chemical Geology, v. 66, pp. 163-177.

Roser, B.P., and Korsch, R.J., 1986, Determination of tectonic setting of sandstone-mudstone suites using $\mathrm{SiO}_{2}$ content and $\mathrm{K}_{2} \mathrm{O} / \mathrm{Na}_{2} \mathrm{O}$ ratio. The Journal of Geology, v. 94(5), pp. 635-650.

Selvaraj, K., and Chen, C.T.A., 2006, Moderate chemical weathering of subtropical Taiwan: constraints from solid-phase geochemistry of sediments and sedimentary rocks. Journal of Geology, v. 114, pp. 101-116.

Selvaraj, K., Lin, B.Z., Lou, J.-Y., Xia, W.L., Huang, X.T., and Chen, C.T.A., 2016, Lacustrine sedimentological and geochemical records for the last 170 years of climate and environmental changes in southeastern China. Boreas, v. 45, pp. 165-179.

Selvaraj, K., Parthiban, G., Chen, C.T.A., and Lou, J.Y., 2010, Anthropogenic effects on sediment quality off southwestern Taiwan: assessing the sediment core geochemical record. Continental Shelf Research, v. 30, pp. $1200-1210$.

Seong, Y.B., Owen, L.A., Lim, H.S., Yoon, H.I., Kim, Y., Lee, Y.I., and Caffee, M.W., 2009, Rate of late Quaternary ice-cap thinning on King George Island, South Shetland Islands, West Antarctica defined by cosmogenic ${ }^{36} \mathrm{Cl}$ surface exposure dating. Boreas, v. 38, pp. 207-213.
Simms, A.R., Milliken, K.T., Anderson, J.B., and Wellner, J.S., 2011, The marine record of deglaciation of the South Shetland Islands, Antarctica since the Last Glacial Maximum. Quaternary Science Reviews, v. 30, pp. $1583-1601$.

Smellie, J.L., Pankhurst, R.J., Thomson, M.R.A., and Davies, R.E.S., 1984, The geology of the South Shetland islands: VI. Stratigraphy, Geochemistry and Evolution. British Antarctic Survey Scientific Reports v. $87,85 \mathrm{p}$

So, C.S., Yun, S.T., and Park, M.E., 1995, Geochemistry of a fossil hydrothermal system at Barton Peninsula, King George Island. Antarctic Science, v. 7(1), pp. 63-72.

Sugden, D.T., and John, B.S., 1973, The ages of glacier fluctuations in the South Shetland Islands, Antarctica. In: van Zinderen Bakker, E.M (Ed.), Palaeoecology of Africa, the Surrounding Islands and Antarctica, v. 8, pp. 141-159.

Verma, S.P., and Armstrong-Altrin, J.S., 2013, New multi-dimensional diagrams for tectonic discrimination of siliciclastic sediments and their application to Precambrian basins. Chemical Geology, v. 355, pp. 117-133.

Willan, R.C.R., and Armstrong, D.C., 2002, Successive geothermal, volcanic-hydrothermal and contact-metasomatic events in Cenozoic volcanic-arc basalts, South Shetland Islands, Antarctica. Geological Magazine, v. 139, pp. 209-231.

Yeo J.P., Lee J.I., Hur S.D., and Choi B.-G., 2004, Geochemistry of igneous rocks in Barton and Weaver peninsulas, King George Island, Antarctica: Correlation with ancient volcanic centers. Geosciences Journal, v. 8, pp. 11-25.

Yoo, C.M., Choe, M.Y., Jo, H.R., Kim, Y., and Kim, K.H., 2001, Volcaniclastic sedimentation of the Sejong Formation (Late PaleoceneEocene), Barton Peninsula, King George Island, Antarctica. Ocean and Polar Research, v. 23, pp. 97-107.

Yoo, K.-C., Lee, M.K., Yoon, H.I., Lee, Y.I., and Kang, C.Y., 2015, Hydrography of Marian Cove, King George Island, West Antarctica: implications for ice-proximal sedimentation during summer. Antarctic Science, v. 27, pp. 185-196.

Yoon, H.I., Park, B.K., Domack, E.W., and Kim, Y., 1998, Distribution and dispersal pattern of suspended particulate metter in Maxwell Bay and its tributary, Marian Cove, in the South Shetland Islands, West Antarctica. Marine Geology, v. 152, pp. 261-275.

Yoon, H.I., Yoo, K.-C., Bak, Y.-S., Lim, H.S., Kim, Y., and Lee, J.I., 2010, Late Holocene cyclic glaciomarine sedimentation in a subpolar fjord of the South Shetland Islands, Antarctica, and its paleoceanographic significance: Sedimentological, geochemical, and paleontological evidence. Geological Society of America Bulletin, v. 122, pp. 1298-1307.

Zaid, S.M., and Gahtani, F.A., 2015, Provenance, diagenesis, tectonic setting and geochemistry of Hawkesbury sandstone (Middle Triassic), southern Sydney Basin, Australia. Turkish Journal of Earth Sciences, v. 24, pp. 72-98.

Zhang, Y., and Gao, X., 2015, Rare earth elements in surface sediments of a marine coast under heavy anthropogenic influence: the Bohai Bay, China. Estuarine, Coastal and Shelf Science, v. 164, pp. 86-93.

Zhou, X., Li, A., Jiang, F., and Lu, J., 2015, Effects of grain size distribution on mineralogical and chemical compositions: a case study from size fractional sediments of the Huanghe (Yellow River) and Changjiang (Yangtze River). Geological Journal, v. 50, pp. 414-433. 

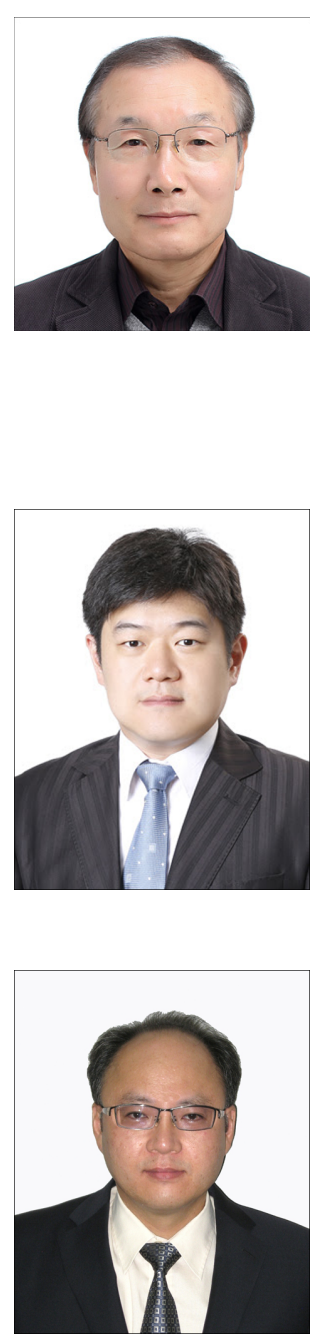

Yong Il Lee is emeritus Professor of Geology in the School of Earth and Environmental Sciences at Seoul National University, Seoul, Korea. He holds BSc and MSc degrees in geology from Seoul National University and $\mathrm{PhD}$ from the University of Illinois at Urbana-Champaign, Illinois, USA He served as President of the Geological Society of Korea (2010-2011). He has authored over 200 scientific publications in the fields of sedimentary petrology, diagenesis, sequence stratigraphy, geochemistry, paleogeography, paleoclimatology, and polar sciences. His research on sedimentary geology has been recognized by the Geological Society of Korea with the Best Paper Award (1995) and the Academic Award (2007) and by the National Academy of Sciences of Korea with the Academic Award (2012). He has also won two Medals from the Korean Government: Republic of Korea Order of Science and Technological Merit (2009) and Republic of Korea Order of Service Merit (2018).

Taejin Choi is an assistant professor of sedimentary geology in the Department of Energy and Resources Engineering, Chosun University, Gwangju, Korea. He received his Ph.D. from School of Earth and Environmental Sciences, Seoul National University, Korea. He has studied provenance and thermal history of sedimentary basins in Korea using petrography, geochemistry, and geochronology of detrital minerals.

Hyoun Soo Lim is an associate professor of sedimentary geology in Department of Geological Sciences, Pusan National University, Busan, Korea. He received his Ph.D. from Seoul National University, Korea. His main research focuses on the low-temperature thermochronology, Quaternary geology, paleoclimate, geoarcheology and polar science. He won the Young Geologist Award from the Geological Society of Korea, and the Challenge Award from the Korea Polar Research Institute. He has served as an associate editor for the Journal of the Geological Society of Korea, and editorial board member for Geosciences Journal. 